\title{
Late Pleistocene spotted hyena den sites and specialized rhinoceros scavengers in the karstified Zechstein areas of the Thuringian Mountains [Central Germany]
}

Cajus Diedrich

How to cite:

DiEDRICH, C. (2015): Late Pleistocene spotted hyena den sites and specialized rhinoceros scavengers in the karstified Zechstein areas of the Thuringian Mountains (Central Germany). - E\&G Quaternary Science Journal, 64 (1): 29-45. DOI: 10.3285/eg.64.1.03

Abstract:

Crocuta crocuta spelaea (GolDFuss 1823) cranial and postcranial remains of the Pößneck region in the Zechstein Karst region of the Thuringian Mountains (Central Germany) were excavated historically in the Wüste Scheuer Cavity at Döbritz. Nearby, at the Krölpa gypsum karst open air site, additionally a woolly rhinoceros, partially scavenged by Ice Age spotted hyenas, was found. The amount at Wüste Scheuer Cavity includes chew damaged Coelodonta antiquitatis remains and is classified herein as communal den type. At both den/scavenging sites, only a small amount of prey material of Late Pleistocene megafauna of rare M. primigenius, mainly C. antiquitatis, E. c. przewalskii, and fewer B. priscus and R. tarandus was accumulated. The dominance of woolly rhinoceros, bison and Przewalski horse bones are typical for hyena bone assemblages in European low mountain regions, where mammoth was nearly absent as a result of topography. In the Thuringian Karst Mountains nine Late Pleistocene Ice Age spotted hyena den sites are identified. Solely hyena dens are present in Zechstein open air gypsum and limestone karstic regions of Bad Köstritz, Krölpa and Fuchsluken Cavities near Saalfeld. In the Wüste Scheuer their remains overlap with Middle Palaeolithic Neanderthal human camp sites, similar as in the Ilsen Cave at Ranis and Lindenthal Cave in Gera, which demonstrates competition for prey and shelter cavities. At such cave sites, bone remains were historically misinterpreted as „solely of Neanderthal human kitchen rubbish" or even as "bone tools" (e.g. "bone scrapers" = woolly rhinoceros tibia bones chewed by hyenas).

Spätpleistozäne Fleckenhyänenhorste und spezialisierte Nashornverwerter in den verkarsteten Zechsteingebieten des Thüringer Waldes [Mittel-Deutschland]

Kurzfassung: $\quad$ Crocuta crocuta spelaea (GolDFuss 1823) craniale und postcraniale Elemente wurden in der Pößneck-Region der ZechsteinkarstRegion im Thüringer Wald (Zentral-Deutschland) in historischer Zeit in der Wüsten Scheuer Kleinhöhle/Abri bei Döbritz ausgegraben. An der nahegelegenen Krölpa-Gipskarstfundstelle wurde ein von eiszeitlichen Fleckenhyänen angefressener Kadaver eines Wollnashorns gefunden. Die geringe Anzahl der Megafaunenreste aus der Wüsten Scheuer Höhlung/Abri umfasst angefressene Coelodonta antiquitatis-Reste und wird hier als Kommunalhorst identifiziert. An beiden Horst/Fressplätzen wurden jeweils weitere Beutetierreste angereichert. Diese stammen von einer Kaltzeitfauna (Spätpleistozän) mit seltenen Knochenresten von M. primigenius, vorwiegend C. antiquitatis, E. c. przewalskii, und wenigen B. priscus sowie R. tarandus. Die Dominanz des Wollnashorns, gefolgt vom Bison und Przewlaksi-Pferd, ist typisch für Hyänen-Knochenakkumulationen in europäischen Mittelgebirgen, wo das Mammut aufgrund der Topographie nahezu abwesend war. In den verkarsteten Thüringer Bergen können neun spätpleistozäne Hyänenhorste identifiziert werden. Reine Hyänenhorste finden sich im Zechstein-zeitlichen Gipskarst und den Kalkstein-Karstgebieten von Bad Köstritz, Krölpa sowie den Fuchsluken-Höhlungen bei Saalfeld. In der Wüsten Scheuer treten diese überlagernd mit mittelpaläolithischen Lagerplätzen auf, wie auch in der Ilsenhöhle bei Ranis und der Lindenthaler Hyänenhöhle bei Gera, was auf Konflikte um Beute und Unterkünfte hindeutet. An diesen Höhlenfundplätzen wurden Knochenreste historisch inkorrekt als reine „Neanderthaler-Küchenabfälle“ oder als „Knochenwerkzeuge“ (z.B. „Hohlschaber“ = von Hyänen angefressene Wollnashorn-Tibien) interpretiert.

Keywords: $\quad$ Ice Age spotted hyenas, den types, Late Pleistocene, Thuringian Mountains, Central Germany

Address of author:

C. Diedrich, PaleoLogic Private Research Institute, Petra Bezruce 96. CZ 26751 Zdice, Czech Republic. www.paleologic.eu and University Koblenz-Landau, Institute of Integrated Natural Sciecnes, Department of Biology, Universitätsstrasse 1, D-56070 Koblenz. E-Mail: cdiedri@gmx.net

\section{Introduction}

Hyena den research in Germany

Modern spotted hyenas Crocuta crocuta crocuta (c.f. Mills o Mills 1977, LAM 1992, LANSING et al. 2007, Pokines et al. 2007, Kunn et al. 2008) and Late Pleistocene Crocuta cro- cuta spelaea were responsible for most of the non-human and non-cave bear bone accumulations in the Late Pleistocene of Europe (e.g. Fosse et al. 1998, STINER 2004, ViLla et al. 2004; DiEDRICH ひ Žák 2006, DiedRICH 2014a). Their prey bone accumulations are important to reconstruct the palaeoenvironment and landscape, seasonal hunting or 
prey specialization of the last hyena clans of Europe (e.g. Tournepiche \& Couture 1999; Diedrich 2014a). They become a more and more important tool in distinguishing Palaeolithic "kitchen rubbish" from "hyena rubbish" bone sites. Research started for the Late Pleistocene period especially in France due to the abundant "archaeological cave sites" (e.g. Fosse et al. 1998) but was discontinued at German sites (cf. history of Late Pleistocene hyena research in Europe in DiEDRICH 2014a). Hyena den research already begun with the famous works of BuckLAND in 1823 at the German Bavarian Kuhloch Cave and English Kent's Cavern (Buckland 1823), and was continued in Germany by the German biologists Giebel (Martin-Luther University Halle-Saale) who collected between 1847-1850 and described preliminary the first gypsum karst open air hyena den sites Westeregeln and Seveckenberge (GIEBEL 1850, 1851). The Late Pleistocene Westeregeln overlapping Neanderthal camp/hyena den site was recently excavated and studied (DIEDRICH 2012a). Historically, the German hyena den research was then continued by Nehring, who excavated and focused on three open air gypsum karst sites in North/Central Germany: Westeregeln, Seveckenberge and Thiede (Nehring 1876). He also worked on material from cave sites in karstified areas of the Sauerland region (NeHRING 1890). These sites have been partly restudied, including the famous Teufelskammer Cave, the Neanderthal holotype skeleton Kleine Feldhof Cave and the famous cave bear/hyena den Perick Caves (DiEdRICH 2005, 2010a, 2011a, c, 2014a). Since historical research times, when bones were found in larger amounts in karst regions due to manual work techniques, the hyena research was discontinued in Germany. At overlapping Neanderthal camp and hyena den sites, archaeologists mostly included simply "all bones to be of human kitchen rubbish origin". This was recently discussed e.g. for the famous German Palaeolithic and overlapping hyena den Balve Cave site (cf. Diedrich 2011c). The most famous Thuringian cave, the "Lindenthaler Hyänenhöhle" at Gera, was described in historic times also only as hyena den (LieBE 1876). Also the material of the WicHEDORFF (1930) excavations from the karstified Zechstein areas of the Thuringian Mountains of Central Germany (Fig. 1) belongs to this time. It is a part of a large collection of Late Pleistocene mammal bones especially from various hyena den sites of Germany formerly housed in the Preußische Geologische Landesanstalt Berlin, surviving the two World Wars (cf. DiedRICH 2011a, 2012a, 2014a-b).

\section{Early to Late Pleistocene hyena den sites in Thuringia}

Early Pleistocene open air hyena den sites in Thuringia were discovered and extensively excavated at Untermassfeld. This is a well excavated locality with a well documented fauna, which was misunderstood in its bone accumulation taphonomy ("bone accumulation due to river floods" after KAHLKE 2006). Based on his descriptions and detailed surface documentation of the bone distribution it can be classified as one of the most typical open air commuting or even birth den sites. There, hyena remains of even a larger hyena Pachycrocuta were found. Additionally, many coprolites were found among thousands of prey bones. The noncave position (= open air hyena den) underlines the prob- lem of the former assumption of the restriction of Pleistocene hyena dens to caves.

Late Pleistocene hyena dens in Thuringian caves were described as having the richest but not well studied or figured C. c. spelaea material. These caves include the Lindenthal Hyena Cave of Gera (cf. LieBe 1876), the Ilsen Cave (cf. Hülle 1977), and the Fuchsluken Cavities at the Rote Berg near Saalfeld (DiEdRICH 2009, Fig. 1B). The latter site is still under furtherinvestigation. The first single Late Pleistocene Ice Age spotted hyena tooth remain findings from Thuringia are from the Leuschner 1883 collection (Figs. 3.2-4), which are housed now in the British Museum of Natural History London, described as having been found in a "Thuringian Cave". Those remains might have been collected most probably in the Wüste Scheuer Cavity/Abri locality. The year of its labelling (1869) fits to the research history of the excavations and discovery history compared to other sites in Thuringia (cf. LiEBE 1876, EIsel 1886, GÄBler 1928, WichedorfF \& Goetze 1930, Götze 1930, Auerbach 1930, Meyer 1933). In these karstified low mountains, in the northern part of the Permian Zechstein limestones, several smaller caves/cavities or abris are present (cf. WICHEDORFF 1931, WichEDORFF ひ Goetze 1930; Fig. 1A). The bone preservation compared to the other sites (Fig. 1B) fits best to the Wüste Scheuer Cavity/Abri site (possibly also Krölpa or Bad Köstriz). Open air and small cavity/abri air sites have been overlooked in many cases in Thuringia in the past, also by WicHEDORFF o Hess (1931) who mentioned the gypsum karst bone-rich site Bad Köstriz (see also BöHmE 2011) which will be identified herein as another hyena den (after new studies of the historical material), or such as the recently described hyena den abri site Wüste Scheuer Cavity/Abri (= "Döbritzer Cave"). There are now several smaller Late Pleistocene spotted hyena dens within the Thuringian Karst being compiled preliminary (Fig. 1; Tab. 3), whereas detail and revision studies on the important historical Lindenthal Hyena Cave and Ilsen Cave bone material must be addressed in the future.

The description of most important Late Pleistocene hyena den sites in Germany is continued herein with studies of further rediscovered historical material from the Central German Thuringian Mountains (Fig. 1A), which support the identification of about three different hyena den site types (cf. DiEDRICH 2014a). For the palaeoethology understanding of the last European hyena populations, cave bear den studies became highly important to understand the feeding/prey ethology of hyenas. Cave bear den sites are important, because it is well-known that in low mountain regions hyenas specialized on "cave bear scavenging" (DiEDRICH 2005, 2011b, 2013b, c, 2014a-b). A cave bear den site in the Thuringian Mountains is solely found within the larger cave system of the Altensteiner Cave near Bad Liebenstein (BRANIEK 2002) west of the studied area (Fig. 1B). This site has no hyena records (confirmed by own observations in the collection of the Naturkundemuseum Schleusingen, which lacks hyena remains), but abundant Ursus spelaeus subsp. (small forms such as U. spelaeus eremus) remains, in which taphonomic cave bear bone studies still lack at this early/middle Late Pleistocene cave bear den site. 


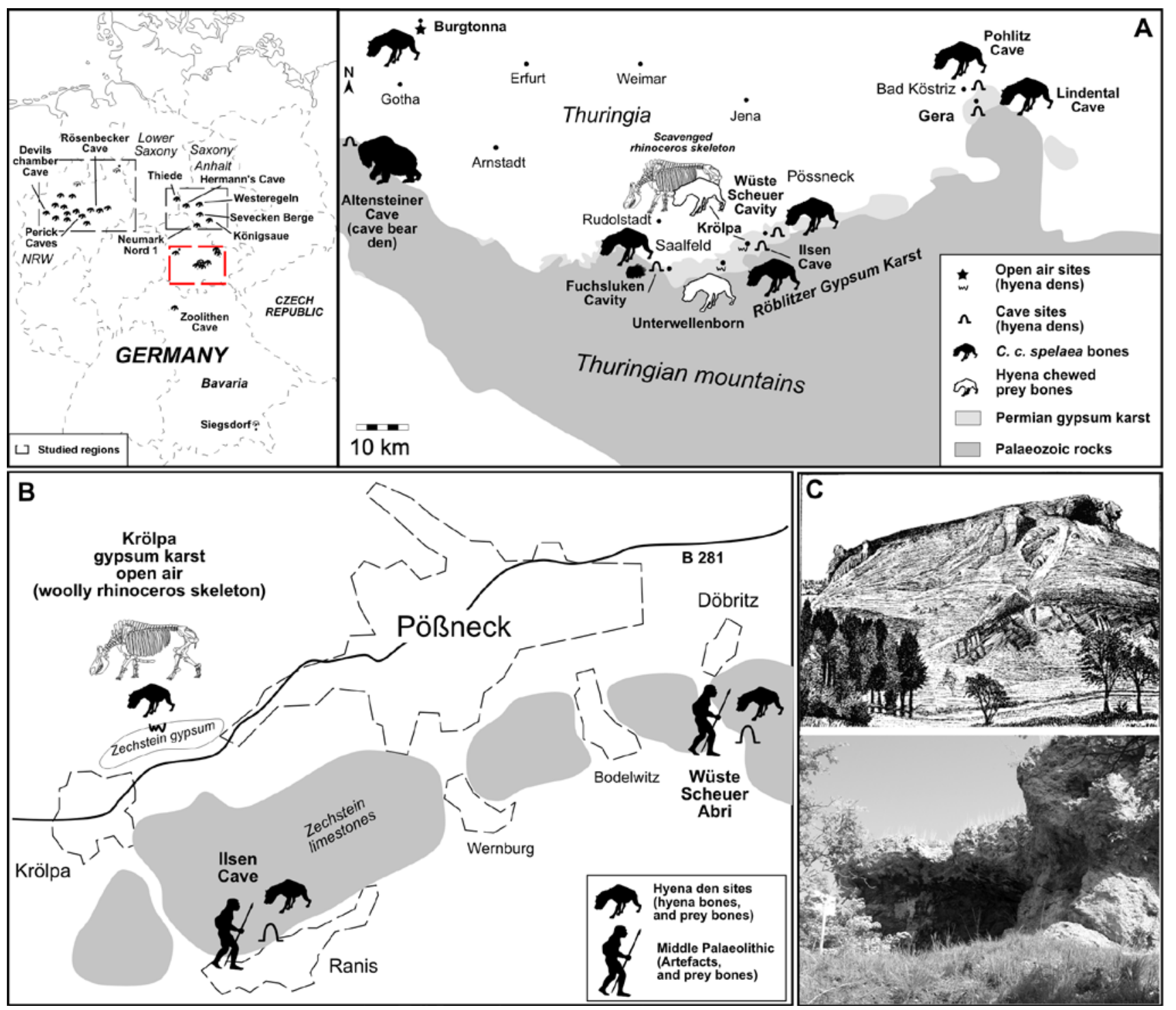

Fig. 1: A. Late Pleistocene small hyena den cave, abri and open air sites in the Zechstein limestone and gypsum karst near Pößneck of Thuringia (Central Germany) and compared studied areas (after DIEDRICH 2012f). C. Wüste Scheuer Abri hyena den site (photo in 2009), and historical picture (from WICHEDORFF \& GOETZE 1930) (right corner of the plateau). (Middle Palaeolithic sites after WICHEDORFF 1930; MÜLLER-BECK 2004).

Abb. 1: A. Spätpleistozäne kleine Höhlen/Abri und Freilandfundstellen im Zechstein Kalk und Gipskarstgebiet um Pößneck in Thüringen (Mittel-Deutschland) und verglichene untersuchte Gebiete (nach DIEDRICH 2012f). C. Wüste Scheuer Abri/Höhlung-Hyänenhorst (Photo 2009), und historische Abbildung (aus WICHEDORFF \& GOETZE 1930) (rechte Ecke des Plateaus). (Mittelpaläolithische Fundstellen nach WICHEDORFF 1930; MÜLLER-BECK 2004).

\section{The Late Pleistocene Wüste Scheuer Abri/Cavity hyena den history}

Near the Thuringian village Pößneck, there are three smaller cavities including the famous "Kniegrotte" and the "Wüste Scheuer Cavity/Abri", where at both sites, in the upper layers remains from the Late Magdalénien period have been found (WichedorfF 1930, Höck 2000, Figs. 1-2A). In the Wüste Scheuer hyena and other Late Pleistocene megafauna remains have been recorded from the "lower layers" such as very few non-diagnostic Middle Palaeolithic flakes, which indicates competition for this shelter, similar as at Gera Lindenthal Cave or Ilsen Cave.

In the Wüste Scheuer south of the village Döbritz (= archaeological monument, Fig. 1B; Lat. 5041'18.15”N; Long. $11^{\circ} 38^{\prime} 30.93$ ”E) initial excavations by EISEL in 1884 yielded first archaeological findings in the upper layers and bone remains of "horse and rhinoceros" in deeper layers (EISEL 1886). The material seems to be partly preserved (e.g.
Late Magdalénian artefacts: Fig. 2B). These discoveries led to complete sediment removal by the "Thürigische Höhlenverein" from the "Döbritzer Höhle bei Pößneck" on the "Öpitzer Berg" (= Wüste Scheuer Abri/Cavity) between 1920-1927 led by Hess von WichedorfF (Berlin). His work focussed on the Late Palaeolithic archaeology (cf. GÄBLER 1928, WichedorfF \& Goetze 1930, Götze 1930). After his excavations parts of the small cave and the fore place were refilled to a plateau (Fig. 1C). The locality was mentioned not only by WiCHEDORFF to have delivered "hyena bones", which was repeated by AuErbach (1930) or MEYer (1933), whereas none of the megafauna remains were figured at that time. Another unpublished document of the city Pößneck supported the former description that the material was partly in the collection of M. RICHTER, which was taken by Prof. BöHм before 1955 to the Landesamt für Archäologie Thuringia in Weimar, but this material can no longer be located, after authors requests. The Late Pleistocene hy- 


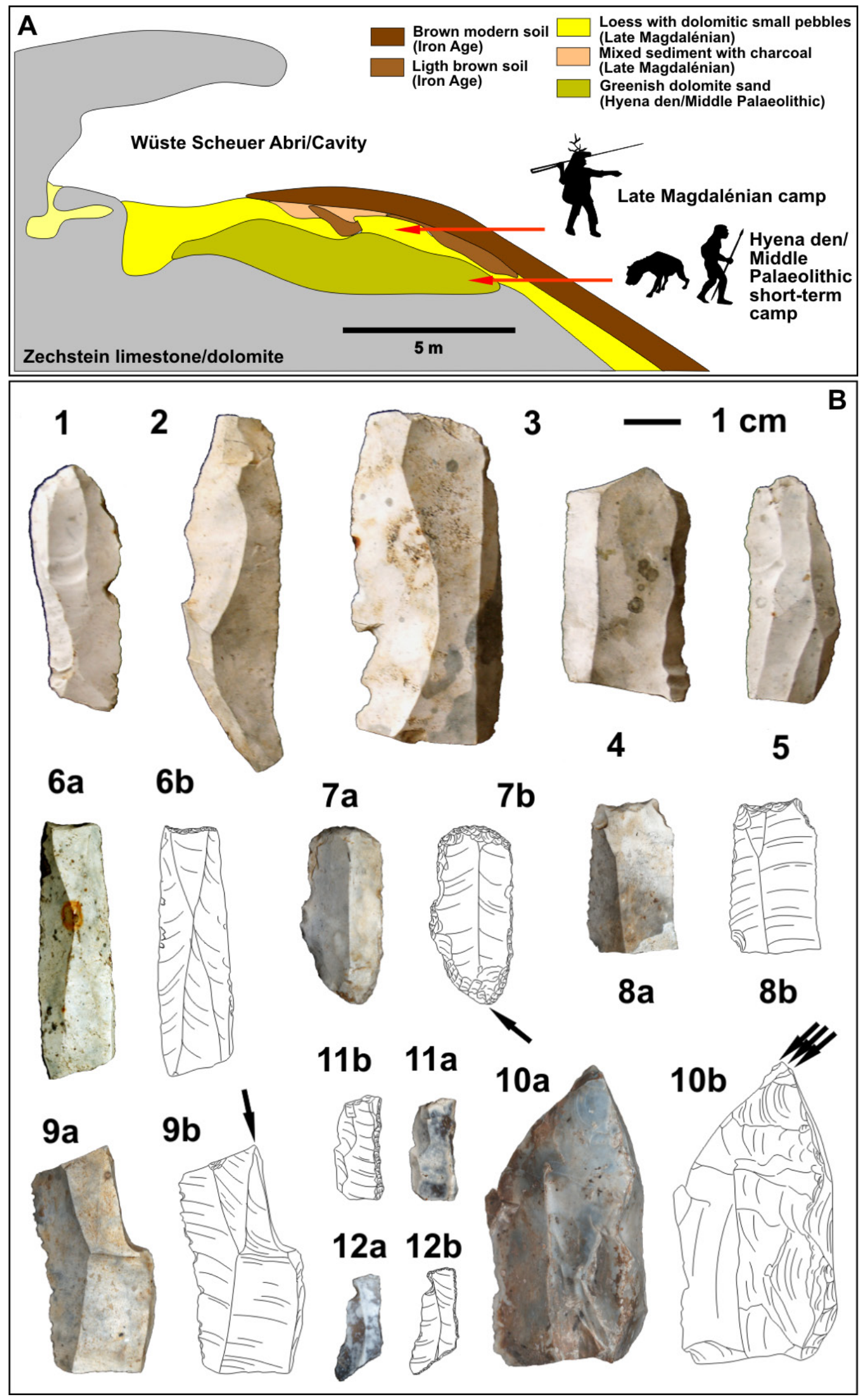

Fig. 2: A. Section sketch redrawn after WICHEDORFF (1930), B. Late Magdalénian flintstone artefacts: 1-5. blades, 6 and 8. distal retouched blade, 7. double scraper, 9-10. burins, 11-12. Backed bladelets (coll. SMS).

Abb. 2: A. Stratigraphie-Übersicht umgezeichnet nach WICHEDORFF (1930), B. Spät-Magdalénian Feuerstein-Artefakte: 1-5. Klingen, 6 und 8. Endtretuschierte Klinge, 7. Doppelkratzer, 9-10. Stichel, 11-12. Rückenmesser (coll. SMS). 
ena skull from "Pößneck" is the most complete one, including its lower jaws (another skull from Lindenthal Cave). It was formerly figured preliminary (KoENIGSWALD 2002), and was compared in the skull shape morphotype analyses with many other skulls of Europe (DIEDRICH 2014a).

\section{The Krölpa rhinoceros carcass open air gypsum karst hyena scavenging site}

Herein, a scavenged "rhinoceros carcass remain" (Coelodonta antiquitatis) from the Krölpa open air gypsum karst (Fig. 1B; Lat.: 5041'4.94”N, Long.: 11³2'48.58”E) west of Pößneck nearby the Wüste Scheuer Cavity hyena den is added, which is important to understand the palaeoecology and body part (not bone) import to hyena den cave sites (= schlep effect), and bone damage stages, which were compared to the open air hyena river terrace site Bottrop (cf. DiEDRICH 2012c) and open air loess site Bad Wildungen (Diedrich 2013a) such as Perick Caves (Diedrich 2006a, 2008b) woolly rhinoceros bone material. There is only a short report about this karstified gypsum depression, which was destroyed during previous historic gypsum quarry activities (cf. WICHEDORFF 1931).

\section{Material and methods}

The studied material is one of the famous historical and "lost collections" from the Geologische Preußische Landesanstalt Berlin, which was recently moved to the Museum of Natural History of the Humboldt-Universität Berlin. Several historical German bone accumulation sites were destroyed during gypsum mining activities, and material, as the herein figured one is important to understand the palaeopopulations of hyenas, their den sites and palaeoecology or -biogeography. Even if the material is incomplete, it is still useful to get a much better understanding of the use of caves by humans or by top predators. This collection demonstrates a much higher density of hyena dens in Central Germany during the times of late Neanderthal and early Late Palaeolithic (Aurignacien) hunter-gatherer occupations. Furthermore it becomes important for distinguishing more clearly between human and top predator bone accumulation sites.

Some hyena teeth were collected at the Wüste Scheuer Cavity possibly before 1883 by Leuschner. These are housed in the British Museum of Natural History in London (abbreviation $=$ BMNHL, collecting/labelling date 1869, Figs. 3.2-4). The EISEL collection was labelled in 1885 (found in 1884) and is at least partly preserved within the Stadtmuseum Saalfeld (abbreviation $=$ SMS) collection with some "lost" Late Magdalénian stone tools figured herein. This flint stone tool material was rediscovered - during a collections management effort of the Pleistocene (another important hyena open air den site Fuchsluken Rote Berg, Saalfeld) and Stone Age (Magdalénian site Teufelsbrücke) artifact collection, made by PaleoLogic in 2009. The here figured hyena bone material (Figs. 3.1, 3.5-22) is from the excavations of WichEDORFF 1920-1927 (now Museum of Natural History of the Humboldt-Universität Berlin: abbreviation = MB). The Pleistocene bones including material from the Krölpa karstified gypsum site (woolly rhinoceros skeleton and other bone material, (Figs. 4-5) were also formerly in the ownership of the "Preußische Geologische Landesanstalt Berlin", then stored after the reform by the Bundesanstalt für Geowissenschaften und Rohstoffe (= BGR) and is now also in the MB. The archaeological collection of WICHEDORFF's excavations went at least partly into the Museum Pößneck, but seems to have been lost during World War II, whereas other material from the Richter collection disappeared in 1955. Possibly this went partly in the Stadtmuseum Saalfeld im Franziskanerkloster (abbreviation $=$ SMS) such as other material of his collection, which was also rediscovered by the author during inventory - work of the Pleistocene fauna and PalaeolithicNeolithic archaeology collection.

The Landesmuseum für Vor- und Frühgeschichte Thüringen permitted a prospection of the old dump (WICHEDORFF excavations) in front of the cave in Mai 2009. Those delivered some Late Magdalénien flint flakes and even tools (one backbladelet, flakes and blades), but also Late Pleistocene bone fragments (yellow in colour similar to the hyena material described herein) from the hyena den period, which are housed now in the Landesmuseum für Vor- und Frühgeschichte Thüringen in Weimar (abbreviation = LAT). Those findings indicate a historical non-sieving and selection of the complete and larger material.

\section{Geology, stratigraphy and dating}

All herein studied Late Pleistocene bone sites are situated in karstified Zechstein limestone or gypsum areas of the northern Thuringian Mountain chain (Figs. 1A-B), which is built mainly of Palaeozoic sediments (SEIDEL 2003).

The Wüste Scheuer Abri/Cavity site section was figured by WichedoRfF (1930, Fig. 2A), whereas newer dating or studies are not possible due to complete sediment removal. The uppermost "brown soil layer" contained already archaeological findings, especially pottery sherds from the Iron Age period. The Late Palaeolithic artefact and bone-rich upper loess layers are from the Late Magdalénian epoch, bearing typical tools of backbladelets, burins and scrapers (mainly flint stone material) and large regular blades (Fig. 2B) and mentioned art work, or abundant shed and cranial attached reindeer antlers such as cranial and postcranial bones (MB collection). This material is similar to the material found in the nearby Kniegrotte (cf. Höck 2000). The oldest layers at the Wüste Scheuer Abri/Cavity contain an "Ice Age fauna" (herein = hyena den bone assemblage), whereas this seems to be mixed with some Middle Palaeolithic artefacts made mainly of local hard river gravel rocks, consisting of scrapers and flakes only (cf. WichedorfF 1930). The megafauna points to an Early to Middle Weichselian age of the Late Pleistocene hyena and little prey material. This age is further supported by the "Middle Palaeolithic" (Moustérien after WichedorfF 1930) artefacts, but those flakes are non-diagnostic for more precise dating into the Eemian or Weichselian. At least, the sparse and likely incompletely preserved megafauna represent a "cold period fauna" sensu e.g. KAHLKE (1955) with the Weichselian species Coelodonta antiquitatuis, Equus caballus przewalski and Rangifer tarandus.

The stratigraphy of the Krölpa gypsum karst open air site is unknown, whereas the karst depressions were 


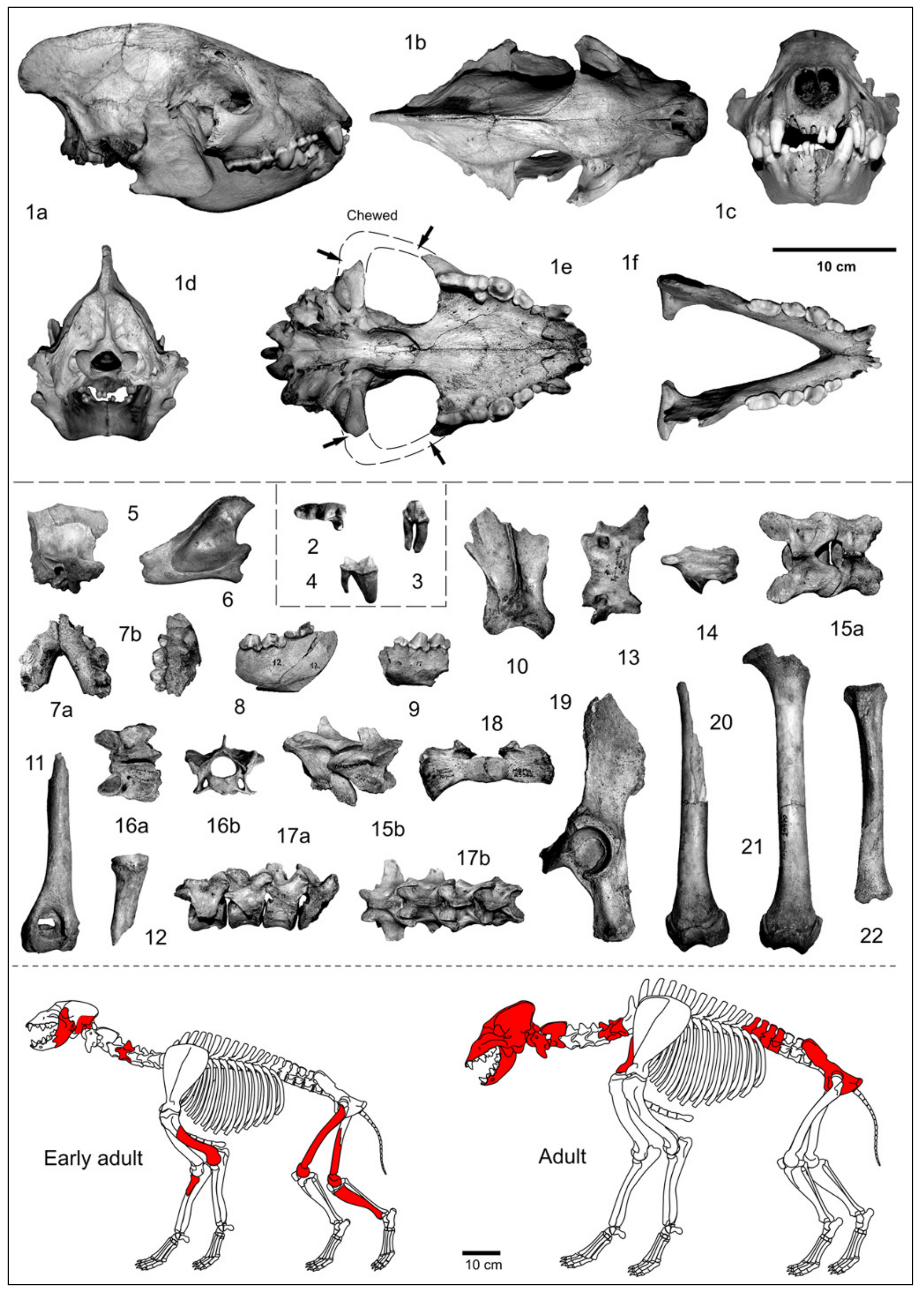


Fig. 3: Late Pleistocene Crocuta crocuta spelaea (GoLDFUSS 1823) remains from the Zechstein gypsum quarry Krölpa hyena open air and the Zechstein limestone Wüste Scheuer Cavity near Döbritz hyena den site both near Pößneck in Thuringia (Central Germany). Krölpa: 1. Skull of a young adult animal. a. lateral right, b. dorsal, c. frontal, d. occipital, e. ventral (MB no. Ma.44381). f. mandible, dorsal. Wüste Scheuer Abri: 2. Right $P^{4}$ of an early adult animal

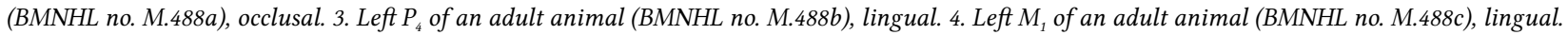
Wüste Scheuer Abri: 5. Brain case fragment of a cub (MB no. Ma.29949), lateral. 6. Lower jaw fragment of a cub (MB no. Ma.29951), lateral. 7. Lower jaw symphyses of a high adult animal (MB no. Ma.29816, 29814), a. dorsal, b. lateral right. 8. Left mandible fragment of a high adult animal (MB no. Ma.29815), lateral. 9. Left mandible fragment of an adult animal (MB no. Ma.29816), lateral. 10. Right scapula of a grown up animal (MB no. Ma. 29964$)$, lateral. 11. Left humerus of a late juvenile animal (MB no. Ma. 29969), cranial. 12. Right radius fragment of a late juvenile animal (MB no. Ma. 29968), lateral inner view. 13. Atlas of a grown up animal (MB Ma. 29952), dorsal. 14. Axes centrum of a grown up animal (MB no. Ma. 29953), dorsal. 15. Cervical vertebrae No. 6 and 7 of a grown up animal (MB no. Ma.29973), a. dorsal, b. lateral. 16. Cervical vertebra No. 3 of a late juvenile animal (MB no. Ma.29954), a. dorsal, b. cranial. 17. Thoracic vertebra No. 13 to Lumbar vertebra No. 2 of a grown up animal (MB no. Ma.29958-29961), a. dorsal, b. cranial. 18. Left coxa of a grown up animal (MB Ma.29967), a. acetabular, b. lateral. 19. Sacrum of a grown up animal (MB no. Ma.29962), cranial. 20. Right incomplete femur of a late juvenile animal (MB no. Ma.29971), cranial. 21. Left femur of a late juvenile animal (MB no. Ma.29970), cranial. 22. Right tibia of a late juvenile animal (MB no. Ma.29972), cranial.

Abb. 3: Spätpleistozäne Crocuta crocuta spelaea (GoLDFUSs 1823)-Reste aus dem Zechstein-Gipskarst-Steinbruch nahe Krölpa und dem Zechstein-Kalk Abri/Höhlung der Wüsten Scheuer nahe Döbritz beide bei Pößneck in Thüringen (Mitteldeutschland). Krölpa: 1. Schädel eines frühadulten Tieres. a. lateral rechts, b. dorsal, c. frontal, d. occipital, e. ventral (MB Nr. Ma.44381), f. Mandibel, dorsal. Wüste Scheuer Abri/Höhlung: 2. Rechter $P_{4}$ eines frühadulten Tieres (BMNHL Nr. M.488a), occlusal. 3. Linker $P_{4}$ eines frühadulten Tieres (BMNHL Nr. M.488b), lingual. 4. Linke $M_{1}$ eines adulten Tieres (BMNHL Nr. M.488c), lingual. Wüste Scheuer Abri/Cavity: 5. Schädelkapsel-Fragment eines fungtieres (MB Nr. Ma.29949), lateral. 6. Unterkieferfragment eines fungtieres (MB Nr. Ma.29951), lateral. 7. Unterkiefersymphyse eines hochadulten Tieres (MB Nr. Ma.29816, 29814), a. dorsal, b. lateral rechts. 8. Unterkieferfragment eines hochadulten Tieres (MB Nr. Ma.29815), lateral. 9. Unterkieferfragment eines adulten Tieres (MB Nr. Ma.29816), lateral. 10. Rechte Scapula eines fungtieres (MB Nr. Ma. 29964), lateral. 11. Linker Humerus eines fungtieres (MB Nr. Ma. 29969), kranial. 12. Rechter radius eines fungtieres (MB Nr. Ma. 29968), lateral Innenseite. 13. Atlas eines ausgewachsenen Tieres (MB Nr. Ma. 29952), dorsal. 14. Axes-Zentrum eines adulten Tieres (MB Nr. Ma. 29953), dorsal. 15. Cervical-Wirbel Nr. 6 und 7eines adulten Tieres (MB Nr. Ma.29973), a. dorsal, b. lateral. 16. Cervical-Wirbel Nr. 3 eines fungtieres (MB Nr. Ma.29954), a. dorsal, b. cranial. 17. Thoracal-Wirbel Nr. 13 tbis Lumbal-Wirbel Nr. 2 eines adulten Tieres (MB Nr. Ma. 29958-29961), a. dorsal, b. cranial. 18. Linke Coxa eines adulten Tieres (MB Nr. Ma.29967), a. acetabular, b. lateral. 19. Sacrum eines adulten Tieres (MB Nr. Ma.29962), kranial. 20. Rechter unvollständiger Femur eines fungtieres (MB Nr. Ma.29971), kranial. 21. Linker Femur eines fungtieres (MB Nr. Ma.29970), kranial. 22. Rechte Tibia eines Jungtieres (MB Nr. Ma.29972), kranial.

described to have been filled up with mainly Late Pleistocene loess (cf. WichedorfF 1931). The presence of the woolly rhinoceros carcass and other previously mentioned cold period megafauna remains (Figs. 3-4) indicate again Weichselian ages of the karst depression fillings.

\section{Results and discussion}

Late Pleistocene spotted hyena den types in Thuringia In contrast to earlier models (cf. CUVIER 1805, Goldfuss 1823, BUCKLAND 1823), we know today from comparisons to modern African spotted hyena dens that hyena dens are not limited to caves only(cf. DiEDRICH 2014a). Hyena den cave sites dominate recently in Central Europe mainly as a result of research history (DIEDRICH 2014a). The most famous hyena den caves in Germany include Lindenthal Cave (D) - Liebe 1876, Teufelslucken Cave (A) - Ehrenberg et al. 1938; Czech Republic: Srbsko Chlum Komin Cave (CZ) - Diedrich 2010b; Sloup Cave (CZ) - Diedrich 2012d; Konĕprusy Cave (CZ) - Diedrich 2012e; Perick Caves (D) - Diedrich 2005, Balve Cave (D) - Diedrich 2011e, Teufelskammer Cave (D) - DiedRIch 2012a, or Rösenbecker Cave (D) - Diedrich 2011a; France: Camiac Cave (F) - GuAdelli 1989, Rochelot Cave (F) - Tournepiche \& Couture 1999; Italy: San Teodoro Cave (It) - MANGANo 2011) and several more cave sites (e.g. Tournepiche 1996, Fosse e al. 1998, DiEDrich \& Žák 2006, Stiner 2004, Villa et al. 2004).

In gypsum karst areas of Germany (Westeregeln, Seveckenberge, Thiede - DiEdRICH 2012a, 2013f, 2014a) and in limestone karst areas (Fuchsluken Cavity - DiEDRICH 2009, 2014a) more and more "bone accumulation sites" were attributed to hyena activities excluding human origins ("kitchen rubbish" of "camp sites", cf. Fig. 1A).

Finally mostly overlooked open air bone accumulation sites have been identified more recently to be of hyena originIn most cases those represent den sites comparable with modern spotted hyenas dens in Africa (cf. e.g. BRAIN, 1983). Newest identifications of such Late Pleistocene hyena open air den site types in Germany are described for different river terrace sites along the Rhine River (DIEDRICH 2008c) and the branching Emscher river at Bottrop (cf. DiEDRICH 2012c), or in short-use overlap with Neanderthal camp lake sites such as Neumark-Nord 1 (DIEDRICH 2010c ) and Königsaue (DIEDRICH 2013f). Another important open air hyena den and bone accumulation type is the recycled badger/fox den open air loess site Bad Wildungen (cf. DiEDRICH 2013a). The den types have recently been reviewed in Europe in terms of the following characteristics a. Morphology and b. Ethology (cf. DiEDrich 2014a).

\section{Late Pleistocene hyena den sites in Thuringia}

About nine Thuringian hyena den sites that contain varying amounts of $C$. c. spelaea bone remains are identified herein for the northern Thuringian Mountain region (Fig. 1A, Tab. 3). Some of the sites cannot be studied anymore (bones lost or distribution in collections unclear, no detailed documentation, and destroyed sites/layers especially in gypsum karst areas). Others (fully excavated Ilsen Cave, destroyed Lindenthal Cave) have to be restudied in future, because artefact records suggest that they overlap with Middle Palaeolithic Neanderthal occupation periods. It is to be expected that the material at those cave sites is a mix of human kitchen rubbish and hyena prey bones, similar as demonstrated for e.g. the Balve Cave hyena and Middle/Late Palaolithic camp cave site (DIEDRICH 2011e) and Westeregeln open air site (DIEDRICH 2012a), being well known also at many French cave sites (e.g. Fosse et al. 1988). 


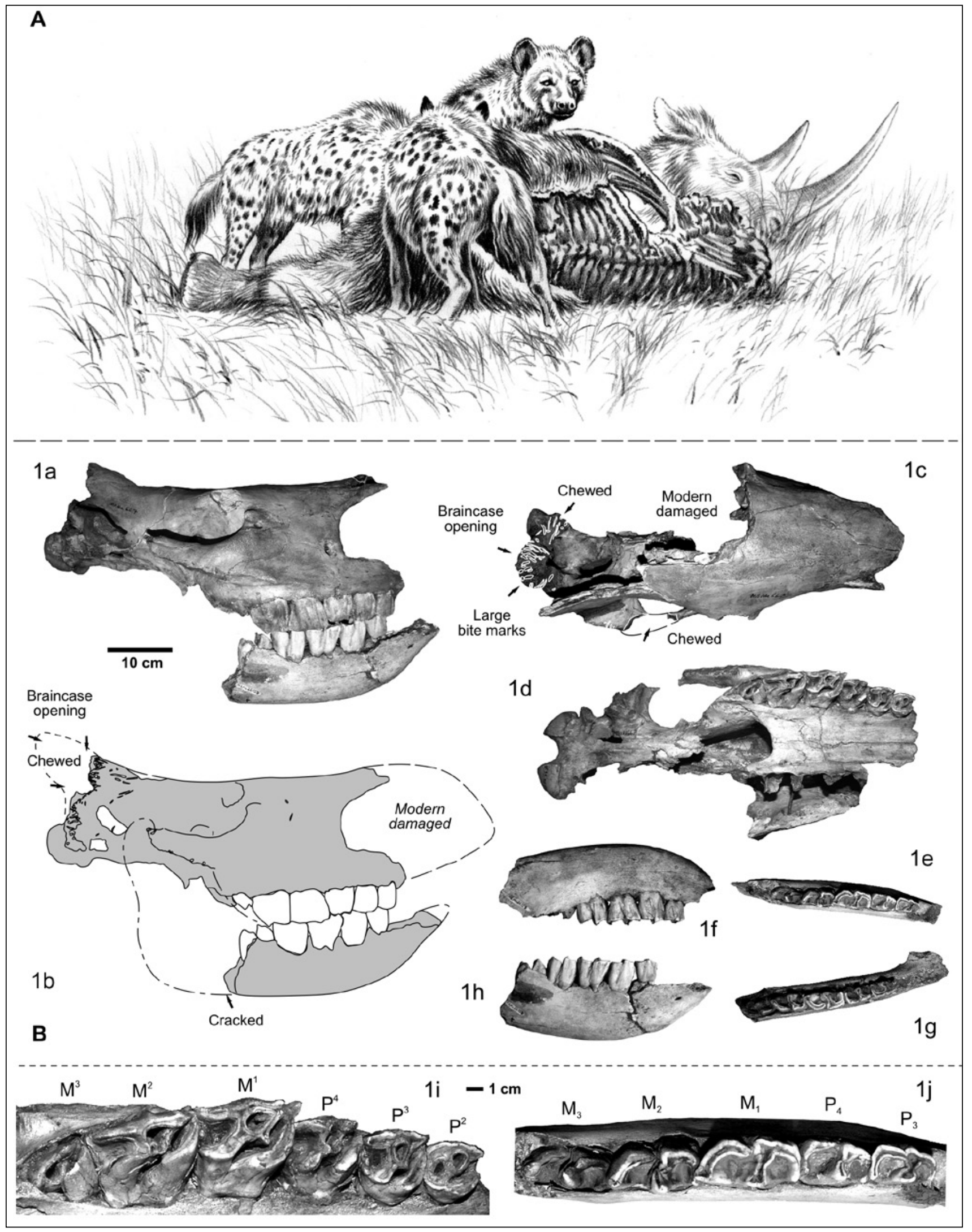

Fig. 4: A. Ice Age spotted hyenas scavenging on Late Pleistocene wooly rhinoceros carcass (Illustration "Rinaldino", G. Teichmann, ๑ PaleoLogic). B. Skull of Coeleodonta antiquitatis (BLUMENBACH 1799) of the skeleton from the Krölpa gypsum karst open air site west of Pößneck in Thuringia (Central Germany). B. Skull with lower jaw (MB no. Ma.26153) and occipital brain case opening caused by hyenas. The skull of an adult rhinoceros belongs most probably to a single skeleton remain (postcranial see Fig. 4), a-b. skull and jaw lateral left, c. dorsal, c. skull dorsal, d. skull ventral, e and g. mandibles dorsal, $f$ and $h$. mandibles lateral, i. right upper jaw dentition, j. left lower jaw dentition.

Abb. 4: A. Eiszeitliche Fleckenhyänen als Aasfresser an einem spätpleistozänen Wollnashorn-Kadaver (Illustration „Rinaldino“, G. Teichmann, ๑ PaleoLogic). B. Schädel von Coeleodonta antiquitatis (BLUMENBACH 1799) des Skelettrestes der Krölpa Gipskarst-Freilandfundstelle westlich von Pößneck in Thüringen (Mittel-Deutschland). B. Schädel mit Unterkiefer (MB Nr. Ma.26153) und occipitalen Schädelöffnung verursacht durch Hyänen. Der Schädel eines adulten Nashorns gehört offensichtlich zu einem Skelettrest (postcraniale Elemente in Fig. 4), a-b. Schädel und Unterkiefer lateral links, c. dorsal, c. Schädel dorsal, d. Schädel ventral, e und $g$. Mandibeln dorsal, f und h. Mandibeln lateral, i. Rechte Oberkieferbezahnung, j. Linke Unterkieferbezahnung. 


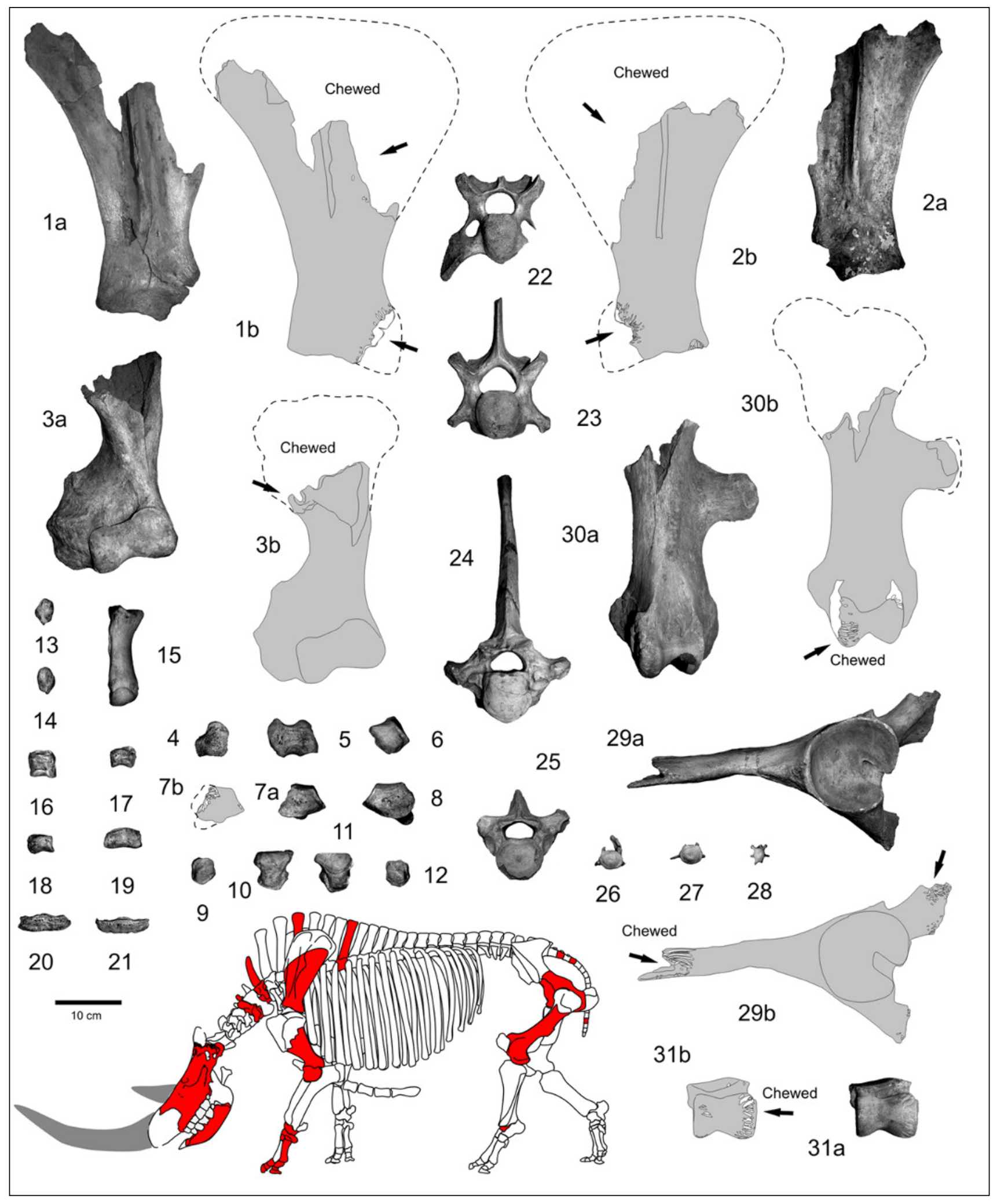

Fig. 5: Postcranial remains of Late Pleistocene Coeleodonta antiquitatis (BLUMENBACH 1799) of one (?or several) skeleton (adult in age) from the Krölpa gypsum karst open air site near Pößneck in Thuringia (Central Germany). 1. Right scapula (MB no. Ma.24947), lateral. 2. Left scapula (MB no. Ma.24.963), lateral. 3. Left humerus (MB no. Ma.16003), cranial. 4. Right ulnare (MB no. Ma.25710.5), lateral. 5. Left radiale (MB no. Ma.25710.2), lateral. 6. Left carpale III (MB no. Ma.25710.3), cranial. 7. Right carpale IV(MB no. Ma.25710.6), cranial. 8. Left carpale IV(MB no. Ma.25710.1), cranial. 9. Right carpale II (MB no Ma.25710.7), cranial. 10. Left internmedium (MB no. Ma.25710.4b), cranial. 11. Right internmedium (MB no. Ma.25710.4a), cranial. 12. Left carpale II (MB no. Ma.25710.8), cranial. 13. Trapezium (MB no. Ma.25710.9), ventral. 14. Trapezium (MB no. Ma.25710.10), ventral. 15. Left metacarpus IV (MB no. Ma.25655), dorsal. 16. Phalanx I (MB no. Ma.25710.11), dorsal. 17. Phalanx II (MB no. Ma.25710.12), dorsal. 18. Phalanx II (MB no. Ma.25710.13), dorsal. 19. Phalanx II (MB no. Ma.25710.14), dorsal. 20. Phalanx III (MB no. Ma.25710.15), dorsal. 21. Phalanx III (MB no. Ma.25710.16), dorsal. 22. Cervical vertebra 5 (MB no. Ma.24902), cranial. 23. Cervical vertebra 7 (MB no. Ma.24927), cranial. 24. Thoracic vertebra 3 (MB no. Ma.24929), cranial. 25. Thoracic vertebra 7 (MB no. Ma.24928), cranial. 26. Upper caudal vertebra (MB no. Ma.29956), cranial. 27. Upper caudal vertebra (MB no. Ma.29955), cranial. 28. Lower caudal vertebra (MB no. Ma.29963), cranial. 29. Left chewed coxa (MB no. Ma.16017), lateral. 30. Left chewed femur (MB no. Ma.16016), cranial. 31. chewed astragalus (MB no. Ma.25710), dorsal. 
Abb. 5: Postcraniale Reste vom spätpleistozänen Coeleodonta antiquitatis (BLUMENBACH 1799) eines (?oder mehrerer) Skelettes (adultes Alter) von der Krölpa Gipskarst-Freilandfundstelle nahe Pößneck in Thüringen(Mittel-Deutschland). 1. Rechte Scapula (MB Nr. Ma.24947), lateral. 2. Linke Scapula (MB Nr. Ma.24.963), lateral. 3. Linke Humerus (MB Nr. Ma.16003), cranial. 4. Rechtes Ulnare (MB Nr. Ma.25710.5), lateral. 5. Linkes Radiale (MB Nr. Ma.25710.2), lateral. 6. Linkes Carpale III (MB Nr. Ma.25710.3), cranial. 7. Rechtes Carpale IV(MB Nr. Ma.25710.6), cranial. 8. Linkes Carpale IV(MB Nr. Ma.25710.1), cranial. 9. Rechtes Carpale II (MB Nr. Ma.25710.7), cranial. 10. Linkes Internmedium (MB Nr. Ma.25710.4b), cranial. 11. Rechtes Internmedium (MB Nr. Ma.25710.4a), cranial. 12. Linkes Carpale II (MB Nr. Ma.25710.8), cranial. 13. Trapezium (MB Nr. Ma.25710.9), ventral. 14. Trapezium (MB Nr. Ma.25710.10), ventral. 15. Linker Metacarpus IV (MB Nr. Ma.25655), dorsal. 16. Phalanx I (MB Nr. Ma.25710.11), dorsal. 17. Phalanx II (MB Nr. Ma.25710.12), dorsal. 18. Phalanx II (MB Nr. Ma.25710.13), dorsal. 19. Phalanx II (MB Nr. Ma.25710.14), dorsal. 20. Phalanx III (MB Nr. Ma.25710.15), dorsal. 21. Phalanx III (MB Nr. Ma.25710.16), dorsal. 22. Cervical-Wirbel 5 (MB Nr. Ma.24902), cranial. 23. Cervical-Wirbel 7 (MB Nr. Ma.24927), cranial. 24. Thoracal-Wirbel 3 (MB Nr. Ma.24929), cranial. 25. Thoracal-Wirbel 7 (MB Nr. Ma.24928), cranial. 26. Oberer Caudal-Wirbel (MB Nr. Ma.29956), cranial. 27. Oberer Caudal-Wirbel (MB Nr. Ma.29955), cranial. 28. Unterer Caudal-Wirbel (MB Nr. Ma.29963), cranial. 29. Linke angefressene Coxa (MB Nr. Ma.16017), lateral. 30. Linker angefressener Femur f (MB Nr. Ma.16016), cranial. 31. Angefressener Astragalus (MB Nr. Ma.25710), dorsal.

In this study the following identified Late Pleistocene hyena den sites from West to East are presented for Thuringia (see details in Tab. 1): 1. Burgtonna as travertin open air spring site, Eemian (KaHLke 1955), 2. Fuchsluken Cavity near Saalfeld, Eemian and Weichselian (DIEDRICH 2008, 2012f), 3. Öpitzer Berg Unterwellenborn open air site (GÄBLER 1928), 4. Krölpa open air site, Weichselian (WichedorfF 1931, an herein), 5. Ilsen Cave Ranis, Weichselian (Utescher ET AL. 1948, MüLler-Beck 2004), 6. Wüste Scheuer Abri/Cavity Döbritz, Weichselian (WichedorfF 1930, an herein), 7. Lindental Cave Gera Weichselian (LIEBE 1876, Auerbach 1930), 8. Pohlitz, Weichselian and 9. Bad Köstritz open air, Eemian and Weichselian (WICHEDORFF o Hess 1931). It is also possible that bones from OppurgPfaffenberg (LiEBE 1876, AUERBACH 1930) are remains of a destroyed hyena den site.

At both cave sites, Lindenthal and Ilsen Caves, "phosphatic layers" must have resulted from long-term use (communal dens), den marking and trampling of their faecal pellets (DIEDRICH 2012b). At all other sites no pellets have been recognized, collected or have survived in collections. Generally, excrements have been documented to be very rare at carcass scavenging sites (DIEDRICH 2010c).

\section{Cannibalistic Ice Age spotted hyena populations around "Pößneck"}

The hyena skull from "Pößneck" (Fig. 3.1) was discussed already in comparison with more than 30 other European skulls to originate from a female in its larger proportions (DIEDRICH 2011a, 2014a), but is still unclear in its original locality (Wüste Scheuer or Krölpa). The bone preservation compared to the other herein figured cranial and postcranial bones would indicate its origin from the Wüste Scheuer. The high amount of hyena remains $(31 \%$ of the bone NISP) at the Wüste Scheuer Abri/Cavity compared to other hyena dens is typical (10-35\%) for Ice Age spotted hyena den sites, e.g. Fosse ET AL. 1998; TournePICHE \& Couture 1999, Villa ET AL. 2004, Diedrich \& Zak 2006; DiEDRICH 2012e, 2014a). The absence of siblings exclude a birth den site compared to modern African spotted hyena birth dens (cf. BrAIN 1983, EAST ET AL. 1989, COOPER 1993, Hofer \& EAST 1995, Boydston et al. 2006), or Ice Age den sites (DIEDRICH 2014a, Fig. 6A). At such dens, remains of siblings were sometimes left as a result of deadly fights between siblings or cubs (cf. FRANK 1994). The age structure statistics of the Wüste Scheuer hyena remains (three main age classes see Fig. 6A), support a communal den and not a birth den type sensu DiEDRICH (2014a).
The skull of Pößneck has postmortal cannibalistic damage on the jugal arches (cf. Fig. 3.1e) resulting from lower jaw removal by hyena scavenging activities (DIEDRICH 2014a). At the Krölpa open air site further damaged hyena cranial remains (three cracked mandibles: Figs. 3.7-9) and one damaged atlas (Fig. 2.13) support hyena cannibalism also at the Thurigian Mountain hyena den sites. The dominance of skulls or in general cranial remains (often abundant isolated teeth, mandible and maxillary fragments) are found at various European open air and even more often at cave sites (there especially in bith dens) (DIEDRICH 2008c, 2011a, 2012h, 2014a, 2015).

\section{The woolly rhinoceros carcass of Krölpa}

The dentition of the rhinoceros skull (Fig. 3B) allows a secure taxonomic attribution to $C$. antiquitatis also compared to a skull of Neumark-Nord Lake 1 site presented by MADE VAN DER (2010). The age of the skull and the fully fused postcranial bone sutures indicate all as adult rhinoceros remains. The absence of repeated bone elements indicates most probably the presence of a single individual. From Krölpa also a single rhinoceros tooth was mentioned (GÄBLER 1928), whereas it remains unclear, if this belongs to the herein figured damaged skull (left row of teeth is missing due to modern/historic damage). Like in the case of Bad Wildungen (DIEDRICH 2013a), it is expected, that nearby the carcass hyenas accumulated other prey remains (G̈̈BLER 1928 also mentioned horse teeth), if the area was used furthermore as den, similar as it happened at Bad Wildungen, where hyenas seem to have reused a badger/fox den in loess sediments (DIEDRICH 2012i).

\section{Hyena den or only open air scavenging site at Krölpa}

Whereas all of the Krölpa carcass rhinoceros longbones and the pelvis (Figs. 5.1-3, 7, 29-30) have 4-6 mm wide bite scratches in the spongiosa, and on the margins triangular and oval bite impact marks also in the compacta, additionally partly zigzag-margins are typical for hyena crushing activities (cf. Diedrich 2012c, Fig. 5). Most interesting is the rhinoceros skull taphonomy. The skull has $4-8 \mathrm{~mm}$ wide and short-elongated large carnivore bite marks inside. Outside again triangular bite impacts and a zigzag margin demonstrate the damage to be the result of breaking scissor dentition of hyenas (cf. DIEDRICH 2012c, 2014a) that opened the skull for feeding on the brain from the occipital. There are only a few other similarly hyena-damaged rhinoceros skulls figured from a calf (Bad Wildungen), and adolescent calf (Selm-Ternsche) (DiEDRICH 2012c, 2013a). Other bite 


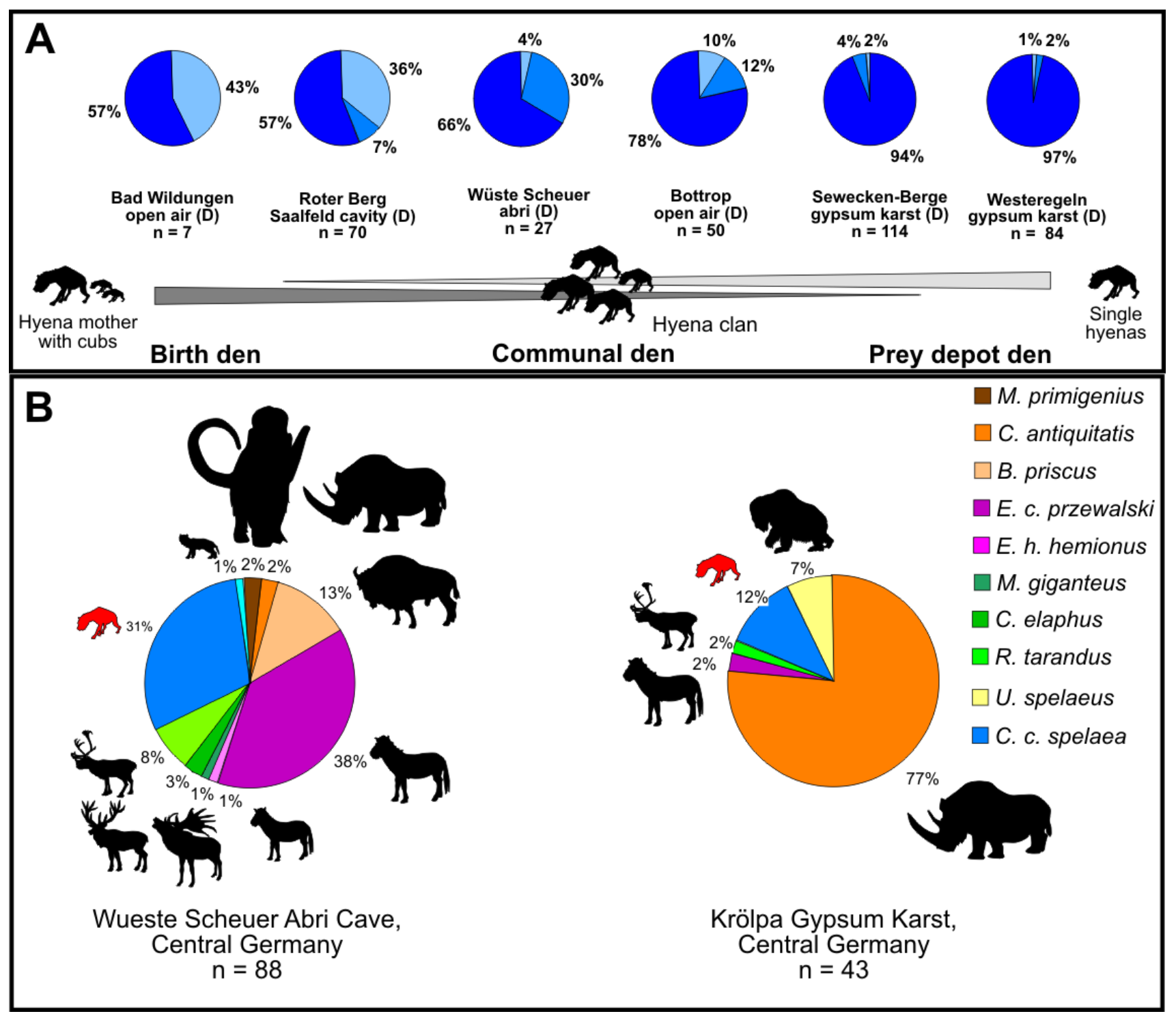

Fig. 6: A. Den types (other sites composed from DIEDRICH 2012e), and B. Faunal compositions at the hyena den sites Wüste Scheuer Abri and Krölpa open air hyena den or scavenging sites (bone amounts composed after GÄBLER 1928, WICHEDORFF 1930, and preserved material of the MB).

Abb. 6: A. Hosttypen (andere Fundstellen zusammengestellt nach DIEDRICH 2012e) und B. Faunenkompositionen an den Hyänenhorst-Fundstellen Wüste Scheuer Abri/Cavity-Horst und Krölpa Freilandfundstellen-Aasfressplatz (Knochen-Anzahl kombiniert aus GÄBLER 1928, WICHEDORFF 1930 und vorhandenem Knochenmaterial im MB).

damages are found at the Krölpa carcass on the right jugal arch (Fig. 4.1c), because hyenas cracked and removed the lower jaws (Figs. 4.1a-b). Skulls with similar jugal arch and lower jaw ramus damages are described from various hyena den caves or open air sites (DIEDRICH \& ŽÁK 2006, DIEDRICH 2008b, 2012a, c, e, 2013a).

The only known German nearly complete articulated woolly rhinoceros skeleton not touched by carnivores, from Petershagen (North-Germany: DIEDRICH 2008a) demonstrates the rareness of articulated carcasses, because those were mostly decomposed by hyena clans throughout Europe (by other predators, or humans). For woolly rhinoceros, the destruction stages of single bones have been already demonstrated at some sites in detail such as for the Perick Caves (Diedrich 2008b), Bad Wildungen Biedensteg open air (DIEDRICH 2012i) and Bottrop open air river terrace hyena den sites with three main longbone destruction stages being repeatedly similar (DIEDRICH 2012c). The rhinoceros carcass damage stages at "death/killing sites" are not well known, except for the Bad Wildungen Biedensteg hyena open air site (DIEDRICH 2012i). Also "in anatomical context" hyena prey remains have been reported for other open air communal dens of Germany at the Achenheim loess site (WERNERT 1968).

The bone remains from Krölpa are similar in their taphonomy and bone NISP assemblage to the open air hyena den loess site Bad Wildungen Biedensteg (cf. Diedrich 2013a). There, also crania of hyenas dominate in the skull record such as woolly rhinoceros prey bone remains exhibiting strong hyena bite damages. Furthermore, possibly one woolly rhinoceros carcass remain was present near the den site. This was found beside the remains of several other individuals including at least one calf carcass remain (braincase opened skull, and chewed longbones and pelvis). The woolly rhinoceros taphonomy of Bad Wildungen is similar to the carcass destruction and incomplete woolly rhinoceros bones of Krölpa. 
Tab. 1: Bone list of Crocuta crocuta spelaea (GoLDFUSS 1823) remains from the region of Pößneck (Thuringia, Middle Germany).

Tab. 1: Knochenliste von Crocuta crocuta spelaea (GoLDFUSS 1823)-Resten aus der Umgebung von Pößneck (Thüringen, Mittel-Deutschland).

\begin{tabular}{|c|c|c|c|c|c|c|c|c|c|c|c|}
\hline No. & Inv.-No. & Bone type & Commentary & left & right & Individual Age & Sex & Bite marks & Original & Old collection & Collection \\
\hline 1 & Ma.44381 & Cranium & $\begin{array}{l}\text { Nearly complete with } \\
\text { mandible, (length } 29.0 \\
\mathrm{~cm}, \mathrm{P} 4 \text { width } 4.1 \mathrm{~cm} \text {, } \\
\text { Lower jaw M1 width } 2.9 \\
\mathrm{~cm}, \mathrm{P} 2 \text { width } 2.1 \mathrm{~cm}\end{array}$ & & & Adult & Male & $\mathrm{x}$ & $x$ & Wichedorff & $\begin{array}{l}\text { Museum für Naturkunde } \\
\text { Berlin }\end{array}$ \\
\hline 2 & Ма.29950 & Cranium & Saggital crest fragment & & & Adult & & $x$ & $\mathrm{x}$ & Wichedorff & $\begin{array}{l}\text { Museum für Naturkunde } \\
\text { Berlin }\end{array}$ \\
\hline 3 & Мa.29951 & Cranium & Brain case fragment & & $x$ & Juvenile & & & $x$ & Wichedorff & $\begin{array}{l}\text { Museum für Naturkunde } \\
\text { Berlin }\end{array}$ \\
\hline 4 & $\begin{array}{l}\text { Ma29816, } \\
29814\end{array}$ & Mandible & $\begin{array}{c}\text { Symphyses, with right P2 } \\
\text { to } 4 \text { [P3 width } 2.2 \mathrm{~cm}\end{array}$ & $x$ & $x$ & High adult & Female & $x$ & $x$ & Wichedorff & $\begin{array}{l}\text { Museum für Naturkunde } \\
\text { Berlin }\end{array}$ \\
\hline 5 & Мa.29815 & Mandible & $\begin{array}{l}\text { Middle fragment with P3 } \\
\text { to } 4, \mathrm{M} 1 \text {, [width } 3.2 \mathrm{~cm}\end{array}$ & $x$ & & High adult & Female & cracked & $\mathrm{x}$ & Wichedorff & $\begin{array}{l}\text { Museum für Naturkunde } \\
\text { Berlin }\end{array}$ \\
\hline 6 & Ма.29816 & Mandible & $\begin{array}{l}\text { Anterior part, with P2 to } \\
\text { 4, [width P3 } 2.3 \mathrm{~cm}\end{array}$ & $x$ & & Adult & Female & & $x$ & Wichedorff & $\begin{array}{l}\text { Museum für Naturkunde } \\
\text { Berlin }\end{array}$ \\
\hline 7 & Ма.29949 & Mandible & Half with ramus & $x$ & & Early adult & & & $x$ & Wichedorff & $\begin{array}{l}\text { Museum für Naturkunde } \\
\text { Berlin }\end{array}$ \\
\hline 8 & Ма.29818 & Tooth & M1 fragment & & & $?$ & & & & Wichedorff & $\begin{array}{l}\text { Museum für Naturkunde } \\
\text { Berlin }\end{array}$ \\
\hline 9 & Ма.29819 & Tooth & Upper jaw P3 & & $x$ & Adult & & & & Wichedorff & $\begin{array}{l}\text { Museum für Naturkunde } \\
\text { Berlin }\end{array}$ \\
\hline 10 & Ma.29964 & Scapula & $\begin{array}{l}\text { Incomplete, Joint width } \\
4.4 \mathrm{~cm}\end{array}$ & & $x$ & Adult & & & $x$ & Wichedorff & $\begin{array}{l}\text { Museum für Naturkunde } \\
\text { Berlin }\end{array}$ \\
\hline 11 & Мa.29969 & Humerus & Without proximal joint & $x$ & & Early adult & & & $x$ & Wichedorff & $\begin{array}{l}\text { Museum für Naturkunde } \\
\text { Berlin }\end{array}$ \\
\hline 12 & Ма.29968 & Radius & Proximal joint & & $x$ & Early adult & & & $\mathrm{x}$ & Wichedorff & $\begin{array}{l}\text { Museum für Naturkunde } \\
\text { Berlin }\end{array}$ \\
\hline 13 & Ma.29962 & Pelvic & Sacrum, fragment & & & Early adult & & & $x$ & Wichedorff & $\begin{array}{l}\text { Museum für Naturkunde } \\
\text { Berlin }\end{array}$ \\
\hline 14 & Мa.29967 & Pelvic & $\begin{array}{l}\text { Fragment, [actetabulum } \\
\text { joint diameter } 3.4 \mathrm{~cm}\end{array}$ & $x$ & & Adult & Male & & $x$ & Wichedorff & $\begin{array}{c}\text { Museum für Naturkunde } \\
\text { Berlin }\end{array}$ \\
\hline 15 & Ма.29966 & Pelvic & $\begin{array}{l}\text { Fragment [actetabulum } \\
\text { joint diameter } 3.6 \mathrm{~cm}\end{array}$ & & $\mathrm{x}$ & Adult & Male & & & Wichedorff & $\begin{array}{l}\text { Museum für Naturkunde } \\
\text { Berlin }\end{array}$ \\
\hline 16 & Мa.29965 & Pelvic & $\begin{array}{l}\text { Fragment [actetabulum } \\
\text { joint diameter } 3.8 \mathrm{~cm}\end{array}$ & $x$ & & Adult & Female & & & Wichedorff & $\begin{array}{c}\text { Museum für Naturkunde } \\
\text { Berlin }\end{array}$ \\
\hline 17 & Ma.29970 & Femur & $\begin{array}{l}\text { Without proximal joint } \\
\text { cap }\end{array}$ & $x$ & & Early adult & & & $x$ & Wichedorff & $\begin{array}{l}\text { Museum für Naturkunde } \\
\text { Berlin }\end{array}$ \\
\hline 18 & Ma.29971 & Femur & $\begin{array}{l}\text { Incomplete proximally, } \\
\text { [distal joint width } 5.2 \mathrm{~cm}\end{array}$ & & $x$ & Early adult & $\begin{array}{c}\text { Female } \\
\text { cub }\end{array}$ & & $x$ & Wichedorff & $\begin{array}{c}\text { Museum für Naturkunde } \\
\text { Berlin }\end{array}$ \\
\hline 19 & Мa.29972 & Tibia & Without joint caps & & $x$ & Early adult & & & & Wichedorff & $\begin{array}{l}\text { Museum für Naturkunde } \\
\text { Berlin }\end{array}$ \\
\hline 20 & Ma.29952 & $\begin{array}{l}\text { Cervical } \\
\text { vertebra }\end{array}$ & Atlas, incomplete & & & Adult & & & $x$ & Wichedorff & $\begin{array}{l}\text { Museum für Naturkunde } \\
\text { Berlin }\end{array}$ \\
\hline 21 & Ma.29953 & $\begin{array}{l}\text { Cervical } \\
\text { vertebra }\end{array}$ & Axes, fragment & & & Adult & & $\mathrm{x}$ & $x$ & Wichedorff & $\begin{array}{l}\text { Museum für Naturkunde } \\
\text { Berlin }\end{array}$ \\
\hline 22 & Ma.29954 & $\begin{array}{l}\text { Cervical } \\
\text { vertebra }\end{array}$ & $\begin{array}{l}\text { No. } 3 \text {, incomplete, } \\
\text { without discs }\end{array}$ & & & Early adult & & & $x$ & Wichedorff & $\begin{array}{c}\text { Museum für Naturkunde } \\
\text { Berlin }\end{array}$ \\
\hline 23 & Мa.29973 & $\begin{array}{l}\text { Cervical } \\
\text { vertebra }\end{array}$ & No. 6, incomplete & & & Adult & & $x$ & $x$ & Wichedorff & $\begin{array}{l}\text { Museum für Naturkunde } \\
\text { Berlin }\end{array}$ \\
\hline 24 & Мa.29974 & $\begin{array}{l}\text { Cervical } \\
\text { vertebra }\end{array}$ & No. 7, incomplete & & & Adult & & $x$ & $x$ & Wichedorff & $\begin{array}{c}\text { Museum für Naturkunde } \\
\text { Berlin }\end{array}$ \\
\hline 25 & Ma.29961 & $\begin{array}{l}\text { Thoracic } \\
\text { vertebra }\end{array}$ & No. 14, incomplete & & & Adult & & $\mathrm{x}$ & $x$ & Wichedorff & $\begin{array}{l}\text { Museum für Naturkunde } \\
\text { Berlin }\end{array}$ \\
\hline 26 & Ma. 29960 & $\begin{array}{l}\text { Thoracic } \\
\text { vertebra }\end{array}$ & No. 15, incomplete & & & Adult & & $x$ & $x$ & Wichedorff & $\begin{array}{c}\text { Museum für Naturkunde } \\
\text { Berlin }\end{array}$ \\
\hline 27 & Ma.29959 & $\begin{array}{l}\text { Lumbar } \\
\text { vertebra }\end{array}$ & No. 1 , incomplete & & & Adult & & $x$ & $x$ & Wichedorff & $\begin{array}{l}\text { Museum für Naturkunde } \\
\text { Berlin }\end{array}$ \\
\hline 28 & Мa.29958 & $\begin{array}{l}\text { Lumbar } \\
\text { vertebra }\end{array}$ & No. 2, incomplete & & & Adult & & $x$ & $x$ & Wichedorff & $\begin{array}{l}\text { Museum für Naturkunde } \\
\text { Berlin }\end{array}$ \\
\hline
\end{tabular}

Prey fauna and comparison of Wüste Scheuer and Krölpa sites

Using the bone list of Eisel in WichEDORFF (1930), and the little material present on the $\mathrm{MB}$ collection, a vague "statistics" is presented (Fig. 6B). However, it is obvious that more bone material is still hidden, lost or was destroyed during the gypsum quarry activities. The incomplete material allowed for identification of the den type and a coarse prey fauna overview. In total, from the lower layers of Wüste Scheuer site (excluding Late Magdalénian), there are only
88 Late Pleistocene bones and teeth, which is little compared to other small European hyena dens (e.g. Fosse et al. 1988, Stiner 2004, Diedrich \& ŽÁx 2006). The high percentage of hyena remains (31\%) is typical at hyena den sites (Fosse et al, 1988, Stiner 2004, Diedrich \& ŽÁk 2006, Diedrich 2014a). In addition, the high amount of horse remains $(38 \%)$ correlates to hyena dens, because Ice Age spotted hyenas were specialized horse hunters in several regions, especially in mountain areas, where they specialized on E. c. przewalski with best examples of the Czech 
Tab. 2: Material of Coelodonta antiquitatis (BLUMENBACH 1799) from the Krölpa open air scavenging site (Thuringia. Middle Germany). Tab. 2: Material von Coelodonta antiquitatis (BLUMENBACH 1799) von der Krölpa-Freiland Gipskarst Aasfresser-Fundstelle (Thüringen, Mittel-Deutschland).

\begin{tabular}{|c|c|c|c|c|c|c|c|c|c|c|c|}
\hline No. & Inv.-No. & Bone type & Commentary & left & right & $\begin{array}{c}\text { Individual } \\
\text { Age }\end{array}$ & Sex & $\begin{array}{c}\text { Bite } \\
\text { marks }\end{array}$ & Original & Old collection & Collection \\
\hline 1 & Ma.26153 & Skull with lower jaw & Incomplete & $\mathrm{x}$ & $x$ & Adult & & $x$ & $x$ & $\begin{array}{c}\text { Wichedorff } \\
\text { [Krölpa bei Pößneck ] }\end{array}$ & $\begin{array}{l}\text { Museum für Naturkunde } \\
\text { Berlin }\end{array}$ \\
\hline 2 & Ma.24.963 & Scapula & Incomplete & $x$ & & Adult & & $x$ & $x$ & Wichedorff & $\begin{array}{l}\text { Museum für Naturkunde } \\
\text { Berlin }\end{array}$ \\
\hline 3 & Ma.24947 & Scapula & Incomplete & & $x$ & Adult & & $x$ & $x$ & Wichedorff & $\begin{array}{l}\text { Museum für Naturkunde } \\
\text { Berlin }\end{array}$ \\
\hline 4 & Мa24948 & Humerus & Incomplete & $x$ & & Early adult & & $x$ & $x$ & Wichedorff & $\begin{array}{l}\text { Museum für Naturkunde } \\
\text { Berlin }\end{array}$ \\
\hline 5 & Ma.16003 & Humerus & Incomplete & $x$ & & Adult & & $x$ & $x$ & Wichedorff & $\begin{array}{l}\text { Museum für Naturkunde } \\
\text { Berlin }\end{array}$ \\
\hline 6 & Ma.25655 & Metacarpus & IV, complete & $x$ & & Adult & & & $x$ & Wichedorff & $\begin{array}{l}\text { Museum für Naturkunde } \\
\text { Berlin }\end{array}$ \\
\hline 7 & Ma.25710.1 & Carpale IV & Complete & $\mathrm{x}$ & & Adult & & & $x$ & Wichedorff & $\begin{array}{l}\text { Museum für Naturkunde } \\
\text { Berlin }\end{array}$ \\
\hline 8 & Ma.25710.2 & Radiale & Complete & $x$ & & Adult & & & $x$ & Wichedorff & $\begin{array}{l}\text { Museum für Naturkunde } \\
\text { Berlin }\end{array}$ \\
\hline 9 & Ma.25710.3 & Carpale III & Incomplete & $x$ & & Adult & & $x$ & $x$ & Wichedorff & $\begin{array}{l}\text { Museum für Naturkunde } \\
\text { Berlin }\end{array}$ \\
\hline 10 & Ma.25710.4 & $\begin{array}{l}\text { Intermedium } \\
\text { [Lunatum] }\end{array}$ & Incomplete & & $x$ & Adult & & $x$ & $x$ & Wichedorff & $\begin{array}{l}\text { Museum für Naturkunde } \\
\text { Berlin }\end{array}$ \\
\hline 11 & Ma.25710.5 & Ulnare & Incomplete & & $x$ & Adult & & $\mathrm{x}$ & $\mathrm{x}$ & Wichedorff & $\begin{array}{l}\text { Museum für Naturkunde } \\
\text { Berlin }\end{array}$ \\
\hline 12 & Ма.25710.6 & $\begin{array}{l}\text { Carpale IV } \\
\text { [Uneiforme] }\end{array}$ & Incomplete & & $x$ & Adult & & $x$ & $x$ & Wichedorff & $\begin{array}{l}\text { Museum für Naturkunde } \\
\text { Berlin }\end{array}$ \\
\hline 13 & Ма.25710.7 & Trapezoideum & Complete & & $x$ & Adult & & & $x$ & Wichedorff & $\begin{array}{l}\text { Museum für Naturkunde } \\
\text { Berlin }\end{array}$ \\
\hline 14 & Мa.25710.8 & Trapezoideum & Complete & $x$ & & Adult & & & $x$ & Wichedorff & $\begin{array}{l}\text { Museum für Naturkunde } \\
\text { Berlin }\end{array}$ \\
\hline 15 & Мa.25710.9 & Trapezium & Complete & & $x$ & Adult & & & $x$ & Wichedorff & $\begin{array}{l}\text { Museum für Naturkunde } \\
\text { Berlin }\end{array}$ \\
\hline 16 & Ma.25710.10 & Trapezium & Complete & $x$ & & Adult & & & $x$ & Wichedorff & $\begin{array}{c}\text { Museum für Naturkunde } \\
\text { Berlin }\end{array}$ \\
\hline 17 & Мa.25710.11 & Phalanx I & Complete & & & Adult & & & $x$ & Wichedorff & $\begin{array}{l}\text { Museum für Naturkunde } \\
\text { Berlin }\end{array}$ \\
\hline 18 & Ma.25710.12 & Phalanx II & Nearly complete & & & Adult & & & $x$ & Wichedorff & $\begin{array}{l}\text { Museum für Naturkunde } \\
\text { Berlin }\end{array}$ \\
\hline 19 & Ma.25710.13 & Phalanx II & Nearly complete & & & Adult & & & $x$ & Wichedorff & $\begin{array}{l}\text { Museum für Naturkunde } \\
\text { Berlin }\end{array}$ \\
\hline 20 & Ma.25710.14 & Phalanx II & Complete & & & Adult & & & $x$ & Wichedorff & $\begin{array}{l}\text { Museum für Naturkunde } \\
\text { Berlin }\end{array}$ \\
\hline 21 & Ma.25710.15 & Phalanx III & Complete & & & Adult & & & $x$ & Wichedorff & $\begin{array}{l}\text { Museum für Naturkunde } \\
\text { Berlin }\end{array}$ \\
\hline 22 & Ma.25710.16 & Phalanx III & Incomplete & & & Adult & & & $x$ & Wichedorff & $\begin{array}{c}\text { Museum für Naturkunde } \\
\text { Berlin }\end{array}$ \\
\hline 23 & Ma.25710.17 & Sesamoid & Complete & & & Adult & & & $x$ & Wichedorff & $\begin{array}{l}\text { Museum für Naturkunde } \\
\text { Berlin }\end{array}$ \\
\hline 24 & Ma.24902 & Cervical vertebra & Inconplete & & & Early adult & & $x$ & $x$ & Wichedorff & $\begin{array}{c}\text { Museum für Naturkunde } \\
\text { Berlin }\end{array}$ \\
\hline 25 & Ma.24927 & Cervical vertebra & C7, incomplete & & & Early adult & & $x$ & $x$ & Wichedorff & $\begin{array}{l}\text { Museum für Naturkunde } \\
\text { Berlin }\end{array}$ \\
\hline 26 & Ma.24929 & Thoracic vertebra & T3, incomplete & & & Early adult & & $x$ & $x$ & Wichedorff & $\begin{array}{l}\text { Museum für Naturkunde } \\
\text { Berlin }\end{array}$ \\
\hline 27 & Мa.24928 & Thoracic vertebra & T7, incomplete & & & Early adult & & $x$ & $x$ & Wichedorff & $\begin{array}{l}\text { Museum für Naturkunde } \\
\text { Berlin }\end{array}$ \\
\hline 28 & Ma.16017 & Pelvis & Coxa & $x$ & & Adult & & $x$ & $x$ & $\begin{array}{c}\text { Wichedorff } \\
\text { [Krölpa bei Pößneck ] }\end{array}$ & $\begin{array}{c}\text { Museum für Naturkunde } \\
\text { Berlin }\end{array}$ \\
\hline 29 & Ma.16016 & Femur & Without proximal joint & $x$ & & Adult & & $x$ & $x$ & Wichedorff & $\begin{array}{l}\text { Museum für Naturkunde } \\
\text { Berlin }\end{array}$ \\
\hline 30 & Ma.25710 & Astragalus & Incomplete & & & Adult & & $x$ & $x$ & Wichedorff & $\begin{array}{c}\text { Museum für Naturkunde } \\
\text { Berlin }\end{array}$ \\
\hline 31 & Ma.25718 & Intermedium & Complete & $x$ & & Adult & & $x$ & $x$ & Wichedorff & $\begin{array}{l}\text { Museum für Naturkunde } \\
\text { Berlin }\end{array}$ \\
\hline 32 & Ma.29956 & Caudal vertebra & Incomplete, proximal & & & Adult & & & $x$ & Wichedorff & $\begin{array}{c}\text { Museum für Naturkunde } \\
\text { Berlin }\end{array}$ \\
\hline 33 & Ma.29955 & Caudal vertebra & Incomplete, proximal & & & Adult & & & $x$ & Wichedorff & $\begin{array}{l}\text { Museum für Naturkunde } \\
\text { Berlin }\end{array}$ \\
\hline 34 & Мa.29963 & Caudal vertebra & Complete, distal & & & Adult & & & $x$ & Wichedorff & $\begin{array}{c}\text { Museum für Naturkunde } \\
\text { Berlin }\end{array}$ \\
\hline
\end{tabular}


Tab. 3: Hyena den sites and den types partly with Middle Palaeolithic overlap in Thuringia (Middle Germany).

Tab. 3: Hyänen-Horstfundstellen und-typen teilweise mit Mittelpaläolithikum-Überlagerung in Thüringen (Mittel-Deutschland).

\begin{tabular}{|c|c|c|c|c|c|c|c|c|c|c|}
\hline No. & Locality & Den type & Den form & Age & $\begin{array}{l}\text { Hyena population } \\
\text { remains [NISP] }\end{array}$ & $\begin{array}{l}\text { Coprolites } \\
\text { and den } \\
\text { marking }\end{array}$ & $\begin{array}{c}\text { Prey } \\
\text { fauna } \\
\text { [NISP] }\end{array}$ & \begin{tabular}{|c|} 
Prey \\
spe- \\
cial- \\
ization
\end{tabular} & $\begin{array}{l}\text { Neanderthal } \\
\text { camp site }\end{array}$ & $\begin{array}{l}\text { Refer- } \\
\text { ences }\end{array}$ \\
\hline 1 & Burgtonna & $?$ & Travertin open air & Eemian & Unclear amount & ? & & $?$ & No & KAHLKE 1955 \\
\hline 2 & $\begin{array}{l}\text { Fuchsluken } \\
\text { Cavity Saalfeld }\end{array}$ & $\begin{array}{c}\text { Birth, and } \\
\text { communal den } \\
\text { open air }\end{array}$ & $\begin{array}{l}\text { Zechstein limestone } \\
\text { karst cavities }\end{array}$ & $\begin{array}{l}\text { Eemian to Middle } \\
\text { Late Weichselian }\end{array}$ & 218 & ? & 1.253 & \begin{tabular}{|c} 
Steppe \\
bison, \\
and \\
Prze- \\
walski \\
horses/ \\
Ice Age \\
donkeys
\end{tabular} & No & $\begin{array}{l}\text { DieDRICH } \\
\text { 2009, } \\
2012 f\end{array}$ \\
\hline 3 & $\begin{array}{l}\text { Opitzer Berg } \\
\text { Unterwellen- } \\
\text { born }\end{array}$ & $?$ & $\begin{array}{l}\text { Zechstein limestone } \\
\text { karst ?den }\end{array}$ & $\begin{array}{l}\text { Early-Middle } \\
\text { Late Weichselian }\end{array}$ & ? & ? & ? & ? & ? & GÃBLER 1928 \\
\hline 4 & $\begin{array}{l}\text { Ilsen Cave } \\
\text { Ranis }\end{array}$ & ? & $\begin{array}{l}\text { Zechstein limestone } \\
\text { cave }\end{array}$ & $\begin{array}{c}\text { Early-Middle } \\
\text { Late Weichselian }\end{array}$ & $\begin{array}{l}\text { ?, but more then } \\
150 \text { remains }\end{array}$ & $\begin{array}{l}\text { "Phosphatic } \\
\text { layer" }\end{array}$ & ? & $?$ & Moustérian & $\begin{array}{l}\text { MüLLER-BECK } \\
2004\end{array}$ \\
\hline 5 & Krölpa & $\begin{array}{l}\text { Communal/ } \\
\text { Prey storage } \\
\text { den and scav- } \\
\text { enging site }\end{array}$ & $\begin{array}{c}\text { Zechstein gypsum karst } \\
\text { open air }\end{array}$ & $\begin{array}{l}\text { Early-Middle } \\
\text { Late Weichselian }\end{array}$ & $\begin{array}{l}\text { Skull, } 2 \text { teeth and } \\
\text { two bones }\end{array}$ & $?$ & 43 & \begin{tabular}{|c} 
Woolly \\
rhino- \\
ceros \\
carcas \\
scaven- \\
ging \\
\end{tabular} & No & $\begin{array}{l}\text { WICHEDORFF } \\
1931\end{array}$ \\
\hline 6 & $\begin{array}{l}\text { Wüste Scheuer } \\
\text { Abri }\end{array}$ & Communal den & $\begin{array}{l}\text { Zechstein limestone } \\
\text { karst abri }\end{array}$ & $\begin{array}{c}\text { Early-Middle } \\
\text { Late Weichselian }\end{array}$ & 27 & ? & 88 & $?$ & Moustérian & $\begin{array}{c}\text { WiCHedurfF } \\
1930\end{array}$ \\
\hline 7 & $\begin{array}{l}\text { Lindenthal } \\
\text { Cave Gera }\end{array}$ & & $\begin{array}{l}\text { Zechstein limestone } \\
\text { cave }\end{array}$ & $\begin{array}{l}\text { Early-Middle } \\
\text { Late Weichselian }\end{array}$ & $\begin{array}{l}\text { ?, but more then } \\
150 \text { remains }\end{array}$ & $\begin{array}{l}\text { "Phosphatic } \\
\text { layer" }\end{array}$ & ? & $\begin{array}{c}\text { Woolly } \\
\text { rhino- } \\
\text { ceros } \\
\text { carcas } \\
\text { scaven- } \\
\text { ging } \\
\end{array}$ & Moustérian & LIEBE 1876 \\
\hline 8 & Pohlitz & $?$ & $\begin{array}{l}\text { Zechstein limestone } \\
\text { karst open airi }\end{array}$ & $\begin{array}{c}\text { Early-Middle } \\
\text { Late Weichselian }\end{array}$ & $?$ & $?$ & ? & ? & No & $\begin{array}{l}\text { WichedorfF \& } \\
\text { Hess } 1931\end{array}$ \\
\hline 9 & Bad Köstritz & ? & $\begin{array}{c}\text { Zechstein gypsum karst } \\
\text { open air }\end{array}$ & $\begin{array}{l}\text { Early-Middle } \\
\text { Late Weichselian }\end{array}$ & ? & ? & ? & ? & ? & $\begin{array}{l}\text { WIIHEDORFF \& } \\
\text { HESS } 1931\end{array}$ \\
\hline
\end{tabular}

Srbsko Chlum-Komín Cave (DiEdrich 2010b) or the French Rochelot Cave (Tournepiche \& Couture 1999). The reindeer percentage $(8 \%)$ of the Wüste Scheuer is vague, because it must be expected, that Magdalénian remains are mixed at least in the historical reports. The absence of cave bear and mammoth remains are comparable to the statistics for boreal forest mountain region hyena den bone assamblages, where cave bear dens are absent or rare (cf. DIEDRICH 2013C, 2014a). The Thuringian Mountain region is similar to the Bohemian Karst region, in terms of size and prey fauna bone assemblages of hyena dens (cf. DIEDRICH ¿ ŽÁx 2006). Compared to Krölpa, at Wüste Scheuer 77\% of the NISP represent woolly rhinoceros bones. Thishigh percentage is a result of the presence of a possible $C$. antiquitatis individual carcass (Fig. 6B). Therefore, the high NISP percentage at this site cannot be used to demonstrate a specialization on the important hyena prey.

\section{Conclusions}

In the northern Thuringian Mountains, several cavities and karstic limestone/gypsum depressions and dolines are present in the Central German Zechstein. These areas were used by clans of the last European hyenas, the Ice Age Spotted hyena Crocuta crocuta spelaea (GoLDFuss 1823) mainly for different denning purposes. Hyena dens are more represented in small cavity regions. This explains the rareness of cave bears in the studied Thuringian Mountains region where those depended on larger caves for hibernation and birth.

A single larger cave bear den cave was present about 50 $\mathrm{km}$ west of the studied region with the Altensteiner Cave bear den cave. In the Röblitzer Gypsum Karst area only a single undescribed cave bear was recorded in a small cave, whereas few early smaller cave bear remains were found in the Fuchsluken Cavities hyena den near Saalfeld.

About nine Thuringian hyena den sites can be identified as Eemian (1) to Weichselian (9) aged hyena densthat were used in different times (Fuchsluken Eemian to Weichselian) and for different purposes, including 1. birth, 2. communal, and 3. prey storage den sites, similar as found at other German Late Pleistocene localities. These sites are highly important for a. the understanding of hyena prey specialization in different landscapes and b. rhinoceros carcass decomposing techniques of hyenas. The woolly rhinoceros carcass scavenging open air site Krölpa was possibly also a hyena communal den. Material that was historically excavated and can only partly be used for statistics from the Pößneck region, points to three hyena sites includeing the Wüste Scheuer Abri/Cavity, Ilsen Cave and Krölpa gypsum karst open air sites, which are in similar early/middle Late Pleistocene time frame of the Neanderthal occupations of at least three cave sites (Wüste Scheuer Abri/Cavity, Ilsen Cave, Lindenthal Cave). Late Pleistocene megafauna bone material from two different hyena related sites, the Wüste Scheuer Abri/Cavity (= "Döbritzer Cave") in Zechstein limestone and Krölpa open air Zechstein gypsum karst site near Pößneck indicate the presence of Ice Age spotted hyena and their activities in the Thuringian Mountain area (boreal forest conditions). Other more frequented (and more bone-rich) hyena den sites are the Lindenthal Cave in 
Gera (communal and prey storage site), Fuchsluken Cavities near Saalfeld (cub raising and communal den), Pohlitz Cavities, Bad Köstritz gypsum karst open air site, and the Ilsen Cave, whereas also in Burgtonna another den seems to have been present nearby a spring (Eemian travertine site). Overrepresentation of cranial hyena remains is typical at communal den sites such as recorded herein at Krölpa and Wüste Scheuer Abri/Cavity. The prey fauna at both sites, as reconstructed in historical literature, is composed of a glacial guild of very few $M$. primigenius, mainly C. antiquitatis, B. priscus, E. c. przewalskii and R. tarandus. Mainly and very typically damaged are the woolly rhinoceros remains (stage 2 of 3 ). The prey fauna NISP statistics demonstrate mammoth rareness in boreal forest environments (present in the river valleys during migrations) and a specialization on woolly rhinoceros, horses and bisons in the low mountain regions. A similar situation is present at Fuchsluken Cavity, where even rhinoceros are very rare in the prey bone record that is dominated by horses/bovids. Apparently, at the open air Krölpa site a single carcass of an adult individual of $C$. antiquitatis was decomposed and left by hyenas in carcass damage stage 2 (medium strongly decomposed and chewed bones, left in place in damage stage 2). Most remarkable is a brain case opening and lower jaw removal, which has only been reported a few times in Europe. The presence of hyena clans and their den and scavenging sites, and overlap of cavity shelters around Pößneck and in the Thuringian Mountains support prey competition and possible conflicts between hyena clans and Neanderthal humans. Or at least, Neanderthals and hyenas often occupied similar cave/cavity sites (Ilsen or Lindenthal caves), in different years, seasons or time periods.

\section{Acknowledgements}

The research of the bone collection management and scientific work was funded by PaleoLogic, such as prospection and geological field work in 2009. PD. Dr. O. Hampe kindly provided access to the historical collections being housed in the Museum für Naturkunde of Humboldt University, Berlin. The woolly rhinoceros skull was restored by the preparator of the museum, M. Brinkmann. The management of the Ice Age fauna/artefact collections of the Stadtmuseum Saalfeld performed by the author was supported financially especially by Dr. D. Henning. Dr. J. Grünberg from the Landesamt für Denkmalpflege und Archäologie Sachsen-Anhalt in Halle/Saale gave information about the Ilsen Cave material. Access to the material from the Lindenthal Cave was possible due to support of Dr. C. Russe and F. Hrouda. Dr. R. Riedel allowed some material in the Naturkundemuseum Erfurt to be studied by. I thank Mrs. J. Dünkel of the culture department of the city Pößneck for sending the unpublished law conflict documents. Finally R. Fohlert as head of the Thuringian cave club sent historical literature and gave useful local cave information. I thank PD Dr. R. Freund for further critical remarks. The publication is a contribution to the cummulative habilitation of the author at the University Koblenz-Landau (Germany), which is well supported by Prof. Dr. U. Sinsch. Finally, T. Parker, Snohomish County-Roads Maintenance (USA), gave helpful comments and spell-checked the manuscript.

\section{References}

Auerbach, A. (1929): Die Lindentaler Hyänenhöhle bei Gera. - Festschrift des Thüringer Höhlenvereins Thüringer Höhlen I, 4 (4/5): 46-56.

Auerbach, A. (1930): Die vor- und frühgeschichtlichen Altertümer Ostthüringens. - 217 pp., Jena.

Böнme, G. (2011): Vergessene Thüringer - Menschenreste und pleistozäne Wirbeltiere aus der Fundstelle Köstritz. Ein wissenschaftshistorischer Überblick. - Semana, Veröffentlichungen des Naturhistorischen $\mathrm{Mu}-$ seums Schleusingen, 26:97-104.

Brain, C.K. (1983): The Hunters or the Hunted?: An Introduction to African Cave Taphonomy. 365 pp. University of Chicago Press, Chicago.

Braniek, G. (2002): Die Funde von Resten des Höhlenbären (Ursus spelaeus Rosenmüller 1794) aus den Höhlen von Altenstein und Bad Liebenstein. - Schriftenreihe der Thüringer Landesanstalt für Umwelt und Geologie 55: 101-134.

Boydston, E.E., Kapheim, K.M. ¿ Holekamp, K.E. (2006): Patterns of den occupation by the spotted hyaena (Crocuta crocuta). - African Journal of Ecology 44: 77-86.

Buckland, W. (1823): Reliquiae Diluvianae, or observations on the organic remains contained in caves, fissures, and diluvial gravel, and other geological phenomena, attesting the action of an universal deluge. 303 pp., J. Murray, London.

Cooper, S.M. (1993): Denning behavior of spotted hyaenas (Crocuta crocuta) in Botswana. - African Journal of Ecology 31: 178-180.

Cuvier, G.L.C.F.D. (1805): Sur les ossements fossiles des Hyènes. Annales du Musée Histoire Naturelle Paris 6: 127.

Diedrich, C. (2005): Eine oberpleistozäne Population von Crocuta crocuta spelaea (GoLDFuss 1823) aus dem eiszeitlichen Fleckenhyänenhorst Perick-Höhlen von Hemer (Sauerland, NW Deutschland) und ihr Kannibalismus. - Philippia 12(2): 93-115.

DiedRICH, C. (2006a): By ice age spotted hyenas protracted, cracked, nibbled and chewed skeleton remains of Coelodonta antiquitatis (BLUMENBACH 1807) from the Lower Weichselian (Upper Pleistocene) open air prey deposit site Bad Wildungen-Biedensteg (Hessia, NW Germany). - Journal of Taphonomy 4(4), 173-205.

DiEDRICH, C. (2008a): A skeleton of an injured Coelodonta antiquitatis (Blumenbach 1807) from the Upper Pleistocene of north-western Germany. - Cranium 25(1): 1-16.

DiEDRICH, C. (2008b): Eingeschleppte und benagte Knochenreste von Coelodonta antiquitatis (BlumENBACH 1807) aus dem oberpleistozänen Fleckenhyänenhorst Perick-Höhlen im Nordsauerland (NW Deutschland) und Beitrag zur Taphonomie von Wollnashornknochen in Westfalen. - Mitteilungen der Höhlen und Karstforscher 2008(4): $100-117$.

DIEDRICH, C. (2008c): Late Pleistocene hyenas Crocuta crocuta spelaea (GolDFuss 1823) from Upper Rhine valley open air sites and the contribution to skull shape variability. - Cranium 25(2): 31-42.

DieDRICH, C. (2009): Late Pleistocene Hystrix (Acanthion) brachyura LiNNAEUS 1758 from the Fuchsluken cave at the Rote Berg near Saalfeld (Thuringia, Germany) - a porcupine and hyena den and contribution to their palaeobiogeography. - The Open Palaeontological Journa 2008(1): 33-41.

Diedrich, C. (2010a): The Crocuta crocuta spelaea (Goldfuss 1823) population and its prey from the Late Pleistocene Teufelskammer Cave hyena den besides the famous Paleolithic Neanderthal Cave (NRW, NW Germany). - Historical Biology 23(2-3): 237-270.

DiEDRICH, C. (2010b): Specialized horse killers in Europe - foetal horse remains in the Late Pleistocene Srbsko Chlum-Komín Cave hyena den in the Bohemian Karst (Czech Republic) and actualistic comparisons to modern African spotted hyenas as zebra hunters. - Quaternary International 220(1-2): 174-187.

Diedrich, C. (2010c): Die späteiszeitlichen Fleckenhyänen und deren Exkremente aus Neumark-Nord. - Archäologie in Sachsen-Anhalt Sonderband 62: 440-448.

DiEDRICH, C. (2011a): One of Europe's last glacial Crocuta crocuta spelaea (GolDFuss 1823) clans from the Rösenbeck Cave hyena den (Germany) and contribution to cranial shape variability. - Biological Journal of the Linnean Society London 103: 191-220.

Diedrich, C. (2011b): The Late Pleistocene spotted hyena Crocuta crocuta spelaea (GoldFuss 1823) population from the Zoolithen Cave at Gailenreuth (Bavaria, South Germany) - a hyena cub raising den of specialized cave bear scavengers in Boreal Forest environments of Central Europe. - Historical Biology 2011: 1-33.

Diedrich, C. (2011c): Periodical use of the Balve Cave (NW Germany) as a Late Pleistocene Crocuta crocuta spelaea (GoldFuss 1823) den: Hyena 
occupations and bone accumulations vs. human Middle Palaeolithic activity. - Quaternary International 233: 171-184.

Diedrich, C. (2012a): Late Pleistocene Crocuta crocuta spelaea (Goldfuss 1823) clans as prezewalski horse hunters and woolly rhinoceros scavengers at the open air commuting den and contemporary Neanderthal camp site Westeregeln (central Germany). - Journal of Archaeological Science 39(6): 1749-1767.

Diedrich, C. (2012b): Typology of Ice Age spotted hyena Crocuta crocuta spelaea (Goldfuss, 1823) coprolite aggregate pellets from the European Late Pleistocene and their significance at dens and scavenging sites. - New Mexico Museum of Natural History and Science Bulletin 57: 369-377.

Diedrich, C. (2012c): The Late Pleistocene Crocuta crocuta spelaea (GoldFUss 1823) population from the Emscher River terrace hyena open air den Bottrop and other sites in NW-Germany - woolly rhinoceros scavengers and their bone accumulations along rivers in lowland mammoth steppe environments. - Quaternary International 276-277: 93-119.

DiedRICH, C. (2012d): The Ice Age spotted Crocuta crocuta spelaea (GolDFUSS 1823) population, their excrements and prey from the Late Pleistocene hyena den Sloup Cave in the Moravian Karst; Czech Republic - Historical Biology 24(2): 161-185.

DiedRICH, C. (2012e): Europe's first Upper Pleistocene Crocuta crocuta spelaea (Goldfuss, 1823) skeleton from the Koněprusy Caves - a hyena cave prey depot site in the Bohemian Karst (Czech Republic) - Late Pleistocene woolly rhinoceros scavengers. - Historical Biology 24(1): 63-89,

Diedrich, C. (2013a): The Late Pleistocene spotted hyena Crocuta crocuta spelaea (Goldfuss, 1823) open air birth and communal den site Bad Wildungen-Biedensteg (Hesse, NW Germany) - woolly rhinoceros killers and scavengers in a mammoth steppe environment of Europe - ?recycling of badger/fox burrows in loess by hyenas in the Ice Age. - Journal of Geological Research 2013: 1-31.

Diedrich, C. (2013b): Impact of the German Harz Mountain Weichselian ice-shield and valley glacier development onto Palaeolithics and megafauna disappearance. - Quaternary Science Reviews 82: 167-198.

Diedrich, C. (2013c): Extinctions of Late Ice Age cave bears as a result of climate/habitat change and large carnivore lion/hyena/wolf predation stress in Europe. - ISRN Zoology 2013: 1-25.

Diedrich, C. (2013d): Ice Age geomorphological Ahorn Valley and Ailsbach River terrace evolution- and its importance for the cave use possibilities by cave bears, top predators (hyenas, wolves and lions) and humans (Late Magdalénians) in the Frankonia Karst - case studies in the Sophie's Cave near Kirchahorn, Bavaria. - E\&G Quaternary Science Journal 62(2): 162-174.

Diedrich, C. (2013e): Late Pleistocene Eemian Ice Age spotted hyena feeding strategies and steppe lions on their largest prey - Palaeoloxodon antiquus Falconer and Cautley, 1845 at the straight-tusked elephant graveyard and Neandertalian site Neumark-Nord Lake 1, Central Germany. - Archaeological and Anthropological Sciences (in press)

Diedrich, C. (2013f): Seltene Freilandfunde der späteiszeitlichen Fleckenhyäne Crocuta crocuta spelaea (GolDFuss 1823) in Sachsen-Anhalt und Beitrag zu Horsttypen der letzten Hyänen im Jung-Pleistozän von Mitteldeutschland. - Zeitschrift für Mitteldeutsche Vorgeschichte $94: 1-19$.

DiEDRICH, C. (2014a): Palaeopopulations of Late Pleistocene top predator in Europe: Ice Age spotted hyenas and steppe lions in battle and competition about prey. - Paleontology Journal 2014, 1-34.

Diedrich, C. (2014b): Holotype skulls, stratigraphy, bone taphonomy and excavation history in the Zoolithen Cave and new theory about Esper's "great deluge". - E\&G Quaternary Science Journal, 63(1): 78-98.

DieDRICH, C. (2015): Inter-/intraspecies traumatic and dental/arthritic pathologies of cannibalistic Late Pleistocene spotted hyena Crocuta crocuta spelaea (Goldfuss, 1823) populations of Europe. - (submitted).

Diedrich, C. \& Žák, K. (2006): Prey deposits and den sites of the Upper Pleistocene hyena Crocuta crocuta spelaea (GoldFuss 1823) in horizontal and vertical caves of the Bohemian Karst (Czech Republic). Bulletin of Geosciences 81(4): 237-276.

EAst, M.L., Hofer, H., TÜrK, A. (1989): Functions of birth dens in spotted hyaenas (Crocuta crocuta). - Journal of Zoology London 219: 690-697.

Ehrenberg, K., Sickenberg, O, Stifft-Gottlieb, A. (1938): Die Fuchsoder Teufelslucken bei Eggenburg, Niederdonau. 1 Teil. - Abhandlungen der Zoologisch-Botanischen Gesellschaft 17(1):1-130.

EIsEL, R. (1886): Höhlenausgrabung bei Döbritz. - Zeitschrift für Ethnographie $18,50-52$.
Fosse, P., Brugal, J.P., Guadelli, J.L., Michel, P. ひ Tournepiche, J.F. (1998): Les repaires d' hyenes des cavernes en Europe occidentale: presentation et comparisons de quelques assemblages osseux. - In: Economie Prehistorique: Les comportements de substance au Paleolithique. 44-61. XVIII Rencontres internationales d' Archeologie et d' Historie d'Antibes. Editions APDCA, Sophia Antipolis.

Frank, L.G. (1994): When hyenas kill their own. - New Scientist 141: 38-41. GäBLER, R. (1928): Höhlenfunde auf der Öpitzer Berg bei Pößneck aus dem Jahre 1910. - Zeitschrift des Thüringer Höhlenvereins 1(1): 29-30.

Giebel, C.G. (1850) Mitteilungen über das Vorkommen der diluvialen Knochen in der Provinz Sachsen. - Jahresberichte der Naturwissenschaftlichen Vereinigung Halle 3: 12-21.

Giebel, C.G. (1851): Die antediluvialianische Saeugethierfauna Deutschlands. - Jahresberichte der Naturwissenschaftlichen Vereinigung Halle 1852: 219-236.

GöTZE, A. (1930): Die Grotte von Döbritz bei Pößneck (Wüste Scheuer). II. Die vorgeschichtliche Besiedlung der Döbritzer Grotte. - Festschrift des Thüringer Höhlenvereins, Thüringer Höhlen I 4(4/5): 83-92.

GoldFuss, G.A. (1823): Osteologische Beiträge zur Kenntnis verschiedener Säugethiere der Vorwelt. VI. Ueber die Hölen-Hyäne (Hyaena spelaea). - Nova Acta Physico-Medica Academiea Caesarae LeopoldinoCarolinae Naturae Curiosorum. 3(2):456-490.

GuADELLI, J.L. (1989): Étude taphonomique du repairesd'hyènes de Camiac (Gironde, France), élements de comparisation entrée un site naturel et un gisement préhistorique. - Bulletin de l'Association Française pour l'Étude du Quaternaire 2: 91-100.

HÜLLE, W.M. (1977): Die Ilsenhöhle unter Burg Ranis/Thüringen: Eine paläolithische Jägerstation. - Urban \& Fischer, München, pp. 203.

Höск, C. (2000): Das Magdalènien der Kniegrotte - Ein Höhlenfundplatz bei Döbritz, Saale-Orla-Kreis. - 202 pp.

Hofer, H. \& EAST, M. (1995): Population dynamics, population size, and the communal system of Serengeti spotted hyenas. - In: Sinclair, A.R.E., Arcese, P. (Eds.), Serengeti II: Dynamics, Management, and Conservation of an Ecosystem. - University of Chicago Press, Chicago, pp. 332-363.

KAHLKE, H.-D. (1955): Großsäugetiere im Eiszeitalter. - 88 pp., Urania, Leipzig und Jena.

KAHLKE, H.-D. (1978): Das Pleistozän von Burgtonna.Quartärpaläontologie 3: $1-509$.

KAHLKE, R.-D. (2006): Untermassfeld - A late Early Pleistocene (Epivillafranchian) fossil site near Meiningen (Thuringia, Germany) and its position in the development of the European mammal fauna. - BAR International Series 1578: 1-114

Koenigswald, W. von (2002): Lebendige Eiszeit. Klima und Tierwelt im Wandel. - 190 pp., Theiss-Verlag, Darmstadt.

KuHN, B.F., BERgER, L.R. ¿ SkinNer, J.D. (2008): Examining criteria for identifying and differentiating fossil faunal assemblages accumulated by hyaenas. - International Journal of Osteoarchaeology 20(1): 15-35.

LAM, Y.M. (1992): Variability in the behavior of spotted hyaenas as taphonomic agents. - Journal of Archaeological Science 19: 389-406.

Lansing, S.W., Cooper' S.W., Boydston' E.E. \& Holekamp, K.E. (2007) Taphonomic and zooarchaeological implications of spotted hyena (Crocuta crocuta) bone accumulations in Kenya: a modern behavioural ecological approach. - Paleobiology 35(2): 289-309.

LIEBE, K.T. (1876): Die Lindentaler Hyänenhöhle und andere diluviale Knochenfunde in Ostthüringen. - Archäologisches und Anthropologisches Organ der deutschen Gesellschaft für Anthropologie, Ethnographie und Urgeschichte 9: 1-55.

Meyer, H. (1933): Reste diluvialer Tiere und die ältesten Menschenspuren vom Rotenberg bei Saalfeld. - Das Thüringer Fähnlein, Monatsschrift für die mitteldeutsche Heimat II 5: 297-298.

MADE, JAN VAN DER (2010): The rhinos from the Middle Pleistocene of Neumark-Nord (Saxony-Anhalt). - Veröffentlichungen des Landesmuseums für Vorgeschichte Halle/Saale 62: 433-527.

MANGANO, G. (2011). An exclusively hyena-collected bone assemblage in the Late Pleistocene of Sicily: taphonomy and stratigraphic context of the large mammal remains from San Teodoro Cave (North-Eastern Sicily, Italy). - Journal of Archaeological Science 38(12): 3584-3595.

Mills, M.G.L. \& Mills, M. (1977): An analysis of bones collected at hyaena breeding dens in the Gemsbok National Parks. - Annales of the Transvaal Museum 30: 145-155.

Müllek-Beck, H. 2004. Die Ilsenhöhle unter Burg Ranis (Kreis Pösneck). - In: H. Meller (Ed.), Paläolithikum und Mesolithikum. Kataloge zur Dauerausstellung im Landesmuseum für Vorgeschichte Halle Band 1 Halle (Saale) 2004: 201-216. 
Musıl, R. (1962): Die Höhle „Sveduv stůl“, ein typischer Höhlenhyänenhorst. - Anthropos New Series 5(13): 97-260.

Nehring, A. (1876): Ausgrabungen bei Thiede und Westeregeln. - Verhandlungen der Berliner Gesellschaft für Anthropologie, Ethnographie und Urgeschichte 1876: 206-209.

NEHRING, A. (1890): Übersicht über 24 mitteleuropäische Quartär-Faunen. - Zeitschrift der deutschen geologischen Gesellschaft 32: 468-509.

Pokines, J.T., Kerbis \& Peterhans, J.C.K. (2007): Spotted hyena (Crocuta crocuta) den use and taphonomy in the Masai Mara National Reserve, Kenya. - Journal of Archaeological Science 34: 1914-1931.

Rohland, N., Pollack, J.L., Nagel, D., Beauval, C., Airvaux, J., Paabo, S. \& HofReiter, M. (2005): The population history of extant and extinct hyenas. Molecular Biology and Evolution 22(12): 2435-2443.

SEIDEL, G. (2003): Geologie von Thüringen. - 601 pp., Schweizerbart, Stuttgart.

SoERGEL, W. (1937): Die Stellung der Hyaena spelaea GoldFuss aus der Lindentaler Hyänenhöhle bei Gera. - Beiträge zur Geologie von Thüringen 4(5): 171-189.

STINER, M.S. (2004): Comparative ecology and taphonomy of spotted hyenas, humans, and wolves in Pleistocene Italy. - Revue de Paléobiologie 23(2): 771-785.

Tournepiche, J.F. (1996): Les grand mammiferes Pleistocenes de PoitouCharentes. - Paleo 8: 109-141.

Tournepiche, J.F. \& Couture, C. (1999): The hyena den of Rochelot Cave (Charente, France). - Monographien des Römisch-Germanischen Zentralmuseums 42: 89-101.
Utescher, K., Gothan, W.U.E.F. ¿ Mojen, H.P. (1948): Das erdige phosphathaltige Sediment in der Ilsenhöhle von Ranis; seine Entstehung, seine Eigenschaften und seine Beziehungen zur Geschichte der Höhle; Kennzeichen glazialer und interglazialer Verwitterung. - Preussische Geologische Landesanstalt Abhandlungen 1948: 1-26.

Villa, P., Castel, J.-C., Beauval, C., Bourdillat, V. \& Goldberg, P. (2004): Human and carnivore sites in the European Middle Palaeolithic. Similarities and differences in the bon emodification and fragmentation. - Revue de Paléobiologie Genève 23: 705-730.

WeRnerT, P. (1968): Beutestücke der Höhlenhyänen im anatomischen Verband aus Achenheimer Lössen. - Quartär 19: 55-64.

WichedorfF, H.C.H von (1930): Die Grotte von Döbritz bei Pößneck (Wüste Scheuer). I. Allgemeines und Geologie. - Zeitschrift des Thüringer Höhlenvereins 4(4/5): 70-83.

WichedorfF, H.C.H von (1931): Typische Karsterscheinungen an der Oberfläche der Gipslager der Zechsteinformation bei Krölpa und Öpitz unweit Pößneck. - Zeitschrift des Thüringer Höhlenvereins $1(5): 118-124$.

WichedorfF, H.C.H von \& GoEtze, A. (1930). Die Thüringer Höhlen. Festschrift des Thüringer Höhlenvereins. Thüringer Höhlen I 4 (4/5): 69.

WichedorfF, H.C.H von \& Hess, H.C. (1931): Der Gipsstock von Köstritz und die in seinen Kolken, Klüften und Schlotten sowie in seiner Diluvial-Decke enthaltenen diluvial-alluvialen Mischfunde von Tierund Menschenresten. - Die Thüringer Höhlen Band II 5(1931)7: 8-22. 